\title{
SOCIEDADE, ESTADO E EDUCAÇÃO: As várias facetas de Rui Barbosa
}

Maria Cristina Gomes Machado Universidade Estadual de Maringá/CNPq mcgmachado@uem.br

\section{RESUMO:}

Neste artigo analisamos a concepção de Rui Barbosa acerca da Sociedade, do Estado e da Educação. Tomamos como recorte temporal o período de 1878 quando este iniciou sua carreira política até o ano de sua morte, 1923. Para a realização dessa pesquisa utilizamos fontes diversas, tais como: os livros escritos pelo autor, escritos para jornais, cartas, programa de governo apresentado quando de sua campanha à presidente da República, pareceres parlamentares, discurso de paraninfo, entre outros. Tais fontes revelam a luta que o autor travava para divulgar e conseguir adeptos às suas ideias. Partimos do pressuposto de que Rui Barbosa tinha um projeto para a sociedade brasileira no qual buscava sua modernização. Modernizar para o autor significava desenvolver economicamente o país por meio da agricultura e da indústria, estabelecer o trabalho assalariado, constituir uma sociedade republicana, alfabetizar a maior parte da população. Nesse processo a educação tinha importante papel, porém não poderia ser isolada do conjunto das transformações necessárias à sociedade.

Palavras-chave: Educação, História da Educação, Rui Barbosa, Escola Pública.

\section{SOCIETY, STATE AND EDUCATION: The many facets of Rui Barbosa}

\begin{abstract}
:
In this article we analyze the conception of Rui Barbosa on the the Society, the State and Education. We took as a time period, from 1878 when he began his political career until the year of his death, 1923. In order to carry out this research we use various sources, such as the books written by the author, his writings for newspapers, letters, his government program while he was campaigning for president of the republic, parliamentary opinions and also his patron speech, among others. These sources reveal the author's struggle waged to spread and get fans to their ideals. We assume that Rui Barbosa had a project for the Brazilian society which sought its modernization. The author meant a process of modernization which considered the economical development of the country through agriculture, industry, the establishment of salaried work and he would also constitute a republican society by turning literate most of the population. In that process education had an important role, although could not be isolated from all the necessary changes to society.
\end{abstract}

Keywords: Education, History of Education, Rui Barbosa, Public School.

\section{Introdução}

Rui Barbosa (1849-1923) foi um importante intelectual que defendeu a escola pública no Brasil Teve uma intensa atuação na Câmara dos Deputados e no Senado, bem como atuou em várias atividades, revelando muitas facetas a serem estudadas ${ }^{1}$. Ele produziu uma volumosa obra. Os pareceres sobre o ensino se tornaram famosos, neles o autor analisou a situação do Ensino Superior e Primário e elaborou um projeto de Reforma. Os pareceres se intitulam a Reforma do Ensino Secundário e Superior (BARBOSA, v. IX, t. I, 1942) e a Reforma do Ensino Primário e Várias Instituições Complementares da Instrução Pública (BARBOSA,v. X, t. I ao IV, 1947a). 
Estes foram submetidos à discussão na Câmara dos Deputados em 1882 e 1883. O objetivo desses pareceres era analisar o Decreto n. 7.247, de 19 de abril de 1879, de autoria do ministro Carlos Leôncio de Carvalho, o qual reformava o ensino primário e secundário no município da Corte e o ensino superior em todo o Império (MACHADO, 2005).

Para a realização dessa pesquisa utilizamos fontes diversas, tais como: os livros escritos pelo autor, escritos para jornais, cartas, programa de governo apresentado quando de sua campanha à presidente da República, pareceres parlamentares, discurso de paraninfo, entre outros $^{2}$. As diferentes fontes foram fundamentais para que pudéssemos conhecer as ações do autor em diferentes grupos sociais. Tais fontes revelam a luta que o autor travava para divulgar e conseguir adeptos aos seus ideais. Partimos do pressuposto de que Rui Barbosa tinha um projeto para a sociedade brasileira no qual buscava sua modernização. Modernizar para o autor significava desenvolver economicamente o país por meio da agricultura e da indústria, estabelecer o trabalho assalariado, constituir uma sociedade republicana, alfabetizar a maior parte da população.

No processo de modernização, muitas instituições precisavam ser reformadas. Neste sentido, neste artigo nos propomos a analisar a concepção de Rui Barbosa acerca da Sociedade, do Estado e da Educação ${ }^{3}$. Para tanto, tomamos como recorte temporal um período longo da vida do autor, de 1878 quando este iniciou sua carreira política até o ano de sua morte, 1923.

Ao estabelecermos esse período para nossa investigação, buscamos compreender o conjunto da obra do autor, de modo a analisar para além dos textos em que Rui Barbosa se dedicou com mais afinco à causa educacional. Lourenço Filho (1956, p. 91-105) destacou os momentos em que ele voltou-se para a questão educacional: ao redigir os pareceres sobre educação - 1881 a 1883; ao traduzir e adaptar as Lições de Coisas, de autoria de Calkins - 1886; ao tratar sobre educação num discurso pronunciado no Liceu de Artes e Ofícios do Rio de Janeiro - 1882 (BARBOSA, v. IX, t. I, 1948). Estes são os textos mais conhecidos de Rui Barbosa, cabe destacar suas ações como editor da Revista Liga de Ensino, três discursos feitos no Parlamento -1883 - e em artigos publicados em jornais. Em especial, abordamos os artigos no jornal Diário de Notícias, em 1889, e no jornal A Imprensa, em 1899, bem como os discursos proferidos nas campanhas política de 1909 e 1919, na qual fez referência à reforma educacional.

Discutimos, primeiramente, a preocupação de Rui Barbosa com e escola como formadora do cidadão eleitor e do trabalhador nacional, por meio do estudo de dois projetos apresentados no parlamento que é o de reforma eleitoral e o projeto de emancipação do sexagenário. $\mathrm{Na}$ seqüência, mostramos a sua compreensão do papel educativo da Imprensa e do papel do Estado com destaque para as publicações nos jornais Diários de Notícias e A Imprensa. Para finalizar, enfocamos como a educação foi discutida durante suas campanhas como candidato a presidente da República.

\section{RUI BARBOSA: SUA TEORIA E AÇÃO NO PARLAMENTO NO FINAL DO IMPÉRIO.}

Esse polêmico pensador nasceu em 5 de novembro de 1849, na cidade de Salvador, Bahia, a segunda cidade em importância naquele momento no Brasil, com destaque para sua vida cultural e política (GONÇALVES, 2000a). Seus pais, João Barbosa e Maria Adélia Barbosa de Oliveira, estavam urbanizados e inseridos nas camadas médias da época. Seu pai era médico e político, atuou como deputado provincial, entre 1846 e 1848, e deputado geral por duas legislaturas, pelo partido liberal, entre 1863 e 1868.

João Barbosa foi muito cuidadoso com relação à educação dos filhos, Rui Barbosa e sua irmã Brites. Com relação ao filho, buscou desenvolver nele qualidades para ser orador, com ênfase numa formação erudita clássica, no domínio das humanidades e da retórica. Colocou-o para cursar o Ginásio Baiano, de propriedade do Dr. Abílio Borges, futuro Barão de Macaúbas. Este educador estava atento às novidades educacionais e, em seu colégio, abolira o castigo físico, para tanto, proibiu os professores de baterem nos alunos. Seu empenho, em inovar em matéria de 
ensino, era considerado radical, visto que se acreditava que os castigos eram insubstituíveis recursos pedagógicos. Rui Barbosa se destacou nesse Colégio, tendo sido premiado e escolhido orador da turma (GONÇALVES, 2000a).

Rui Barbosa cursou humanidades no ensino secundário, estudou alemão enquanto esperava completar a idade mínima de 16 anos para ingressar na Faculdade de Direito de Recife em 1866. Na faculdade, cursou dois anos do curso jurídico, contudo obteve nota baixa em uma matéria, o que o levou a pedir transferência para São Paulo em 1868. Na outra instituição, ele obteve destaque e fez amizade com eminentes personagens do período, como Castro Alves e Joaquim Nabuco, com os quais compôs a comissão literária da faculdade, bem como outras pessoas que comporiam o cenário político futuro, dentre eles Rodrigues Alves, Martim Cabral, Afonso Pena e Bernardino Pamplona. Em São Paulo, participou ativamente da imprensa local. Sobre sua vida nesta cidade é importante registrar seu envolvimento com os movimentos republicano e abolicionista.

Em 1870, já tendo concluído o curso de direito, retornou à Bahia e distanciou-se desses movimentos, aproximando-se do jornal "O Diário da Bahia", de propriedade de Manoel Dantas, tornando-se um de seus redatores. Iniciou, também, carreira jurídica e tornou-se conhecido por suas qualidades de literato. Seu pai faleceu em 1874, deixando muitas dívidas, que foram, na década posterior, saldadas pelo filho, mas herdou a rede de relações influente da qual havia participado, como o apadrinhamento do Conselheiro Manuel de Souza Dantas ${ }^{4}$. Machado (2002, p. 182), sobre sua atuação nos anos anteriores à sua eleição como deputado provincial, escreve que:

O excesso de trabalho o colocou doente e, junto com Rodolfo Dantas, viajou para a França para descansar numa estação de banhos. Permaneceu quatro meses nesse país. Continuou seu tratamento de saúde no Brasil e depois de curado voltou, com fúria, à atividade no jornal. Havia muito que falar, pois os conservadores estavam se utilizando das idéias liberais, como a Lei do Ventre Livre, proposta por Rio Branco, irritando seus autores e defensores. O partido liberal investia suas forças na questão da eleição direta, sobre ela Rui Barbosa pronunciou vários discursos.

Ficou noivo em 1876 e partiu para a corte, com o intuito de fazer carreira. Na capital, começou a trabalhar como advogado e travou relações com influentes personalidades do mundo político. No Rio de Janeiro contactou Saldanha Marinho que o reaproximou dos antigos colegas da maçonaria que conhecera em São Paulo.

Na loja maçônica, iniciou a discussão sobre a liberdade religiosa. Traduziu o livro "O Papa e o Concílio", de Doellinger, anexando a ele um prefácio maior que o livro. Nesse estudo, concluiu que era urgente a separação entre o Estado e a Igreja. Nesse período, casou-se, todavia permaneceu pouco tempo no Rio de Janeiro, regressou à Bahia e assumiu a direção do jornal.

Sua atuação na imprensa e proximidade com a Família Dantas o levou, em 1878, a eleger-se deputado na província baiana; com esse cargo, iniciou sua vida como parlamentar. Logo em seguida, elegeu-se deputado geral pelo Partido Liberal. Sua ação no partido fez com que ele fosse identificado como liberal, e esse termo foi o mais utilizado para defini-lo. Segundo Gonçalves (2000b, p. 26), o termo liberal era utilizado de forma abrangente, “[...] ora refere-se ao fato de ser membro do Partido Liberal, ora ao fato de ser defensor de idéias anacrônicas, ora, ainda, refere-se ao fato de ser um jurista que pautou sua ação na defesa das liberdades burguesas". Na sequência, enfatizaremos sua ação como membro do Partido Liberal.

Após 1868, o Partido Liberal ficou no ostracismo por quase dez anos, devido à escolha, a partir dessa data, para que os membros do Partido Conservador assumissem a pasta de ministro do Império. A organização política impedia que os liberais participassem do governo. Sobre esta 
questão, Chacon (1979, p.106) escreveu que os dois últimos anos da década de 1860 foram importantes para o liberalismo brasileiro, porque alcançariam afirmação nacional.

O gabinete liberal de Zacarias de Góis e Vasconcelos deixa a Presidência do Ministério e foi substituído por um membro do Partido Conservador, o Visconde de Itaboraí. Esse fato levou ao ostracismo do Partido Liberal que só retornaria ao poder em 1878, marcando também a ascensão desse partido, pois reunidos em torno do Centro Liberal, presidido por Nabuco de Araújo redigiram um Manifesto do Centro Liberal e deixaram claro seu programa de governo [...]: 1. Reforma eleitoral; 2. Reforma policial e judiciária; 3. Abolição do recrutamento; 4. Abolição da Guarda Nacional; 5. Emancipação dos escravos.

Rui Barbosa assumiu, neste período, esse programa de governo na íntegra e, no parlamento, sua atuação foi marcada por intensas críticas, visto que suas posições sempre foram radicais, somada à acusação de que era um político prolixo e fazer discursos extensos ${ }^{5}$. Todavia tais críticas não surtiram efeitos. Ele buscava utilizar de todos os argumentos possíveis em seu favor de modo a destruir os argumentos utilizados por seus opositores. Exemplo marcante dessa sua característica é a extensão dos pareceres acerca da educação, este totaliza cinco volumes que excedem a 1500 páginas. Para apresentar parte da sua atuação como parlamentar, optamos por destacar alguns dos polêmicos projetos que defendeu, como o projeto de reforma eleitoral, de 1881, os pareceres sobre educação, 1882-3, e a discussão da lei do sexagenário, 1884. Os dois últimos projetos não foram aprovados na Câmara, todavia sua leitura é importante para o conhecimento de suas posições.

\section{A atuação na Câmara dos Deputados e o projeto de reforma eleitoral.}

Rui Barbosa participou ativamente da discussão sobre a relação entre sociedade e Estado $^{6}$, no final do Império, essa temática era recorrente. Primeiramente, sua posição defendia um Estado limitado, que respeitasse a soberania do indivíduo, já que este poderia dispor "[...] das criações do seu gênio, da sua vocação, da sua ciência, da sua aplicação laboriosa, consumi-las, permutá-las, negociá-las, onde, quando, como convenha ao interesse do produtor, essa uma das fundamentais necessidades humanas" (BARBOSA, v. V, t. I, 1983, p. 42). Assim, definiu o Estado em um discurso na Câmara Provincial:

Sem religião, sem moral, pelo menos, sem educação, sem indústria, sem comércio, o Estado não subsiste; porque falta-lhe meio, falta-lhe o ambiente, falta-lhe o objeto de suas funções, que é estabelecer derredor de tudo isso uma atmosfera de segurança, de justiça, de paz, onde a satisfação de todas essas necessidades humanas, onde todas essas manifestações de humana atividade girem e se desenvolvam livremente. Mas o que não é condição de vida para o Estado, nem de estabilidade para a ordem, é o protecionismo comercial, a nacionalização artificial da indústria, uma moral privilegiada, uma religião monopolista. Infiltrando no povo essas noções sólidas, educando-o assim, demos-lhe a grande, a simples, a genuína intuição, a intuição liberal do papel do Estado nos governos modernos, do seu ideal. (BARBOSA, v. V, t. I, 1983, p. 46-47).

Em escritos posteriores mostraria a necessidade de uma ação forte do Estado na direção da economia com vistas à sua modernização. Sobre essa sua ação Machado e Araújo (2005, p. 118) escrevem que a posição de Rui Barbosa foi emblemática, ao criticar a monarquia, o Poder Moderador, bem como ao defender o direito ao voto e a separação da Igreja e do Estado, permitindo conforme as circunstâncias a interferência do Estado na vida civil. 
Sua compreensão acerca do papel do Estado ficou clara ao defender o projeto referente ao sistema eleitoral, levado à Câmara pelo Ministro do Império Barão Homem de Melo. José Antônio Saraiva havia apresentado, em linhas gerais, os pontos a serem tratados, com base nesses pontos Rui Barbosa redigiu o projeo de reforma eleitoral, apresentado em 1881, com a mediação do conselheiro Souza Dantas. Nesse projeto, deixou clara sua interpretação sobre o sistema representativo: "A base do nosso regime, a sua única base é a democracia. Na administração dos nossos interesses políticos, a soberania do povo é o alfa e o ômega, o princípio e o fim. [...] Nas nossas instituições orgânicas, portanto, só o elemento popular é eterno, substancial, imutável.” (BARBOSA, v. VII, t. I, 1945, p. 11)

Para ele, tanto à Monarquia quanto à República deveriam eleger, temporariamente, seus representantes, por meio de um pleito eleitoral transparente com base no voto direto com título eleitoral definitivo. O sistema criticado por Rui Barbosa deixava ao arbítrio individual verificar o direito de voto a cada eleição; muitas vezes, aqueles que tinham direito de voto poderiam ser impedidos simplesmente por ser do partido oposto, da mesmo forma, os inaptos poderiam fazê-lo quando do agrado do mesário. Este sistema apresentava sérias irregularidades e mantinham o controle dos coronéis em determinadas regiões do país. A fraude eliminava o estabelecimento legítimo do governo e da democracia, defendidos enfaticamente por Rui Barbosa.

Em que consistia tal projeto? Para Rui Barbosa, ele buscava imprimir ao país um caráter cosmopolita próprio do século XIX, de maneira a estender o direito definitivo de voto para novos eleitores, como os não-católicos, os escravos libertos e os estrangeiros, criando-se, assim, um eleitorado independente, permanente e legalmente constituído. Tal medida contribuiria para o fortalecimento da unidade nacional. "Era preciso absorver o escravo prestes a se tornar homem livre e persuadi-lo ao trabalho sem recorrer ao chicote e, ao mesmo tempo, era preciso dissolver as diferentes nacionalidades dos imigrantes deserdados que para o Brasil afluíam" (MACHADO, 2002, p. 59). Isto possibilitaria diminuir o poder dos grandes proprietários de terras, exercido sobre os eleitores que estivessem sob sua dependência. Uma medida simples, como essa mudança no formato eleitoral, poderia melhorar o estado político, refletindo sobre outros interesses, de maneira a proporcionar boas finanças, prosperidade industrial e aumento dos recursos do país. Era preciso ampliar o capital à construção de estradas e outros melhoramentos que pudessem contribuir para desenvolver a agricultura e as indústrias.

O próprio Imperador Dom Pedro II era favorável à reforma, havia, assim, uma certa unanimidade para que fosse adotado o sistema direto, contudo, encontrava-se discordância sobre como deveria ser realizada. O projeto apresentado não previa, ainda, o sufrágio universal, como na Europa, mas elevava o censo eleitoral de $200 \$ 000$ para $400 \$ 000$ e excluía o voto do analfabeto. (BARBOSA, v. VII, t. I, 1945, p. 10-11). Discutia-se, arduamente, a capacidade eleitoral, somente poderiam votar quem soubesse ler e escrever e possuir renda anual mínima de quatrocentos mil réis. Esta renda se justificava, por permitir ao futuro cidadão eleitor independência financeira. Para Rui Barbosa, o sufrágio universal só poderia ser adotado em uma era de inteligência e de educação popular ainda inexistente no Brasil. ${ }^{7}$ Assim, não excluía os analfabetos, mas os estimulava a se alfabetizar. Ele enfatizava que não estava propondo nada novo e buscava copiar democracias, citou os Estados Unidos, em que o número de analfabetos era pequeno, mas, mesmo assim, estavam proibidos de votar. No Brasil, por sua vez, eles eram a maioria e decidiriam os pleitos eleitorais. A medida necessária para ampliar o número de votantes deveria ser aumentar o número de escolas e os investimentos na educação do cidadão, só assim ele poderia participar da democracia.

Replicais: Se abundam os analfabetos, é porque rareiam as escolas. Mas nem isso é razão que demonstre a capacidade eleitoral dos analfabetos; nem o temor da preponderância dos analfabetos é o móvel mais plausível para incitar o governo à multiplicação das escolas; nem o estímulo que há de avivar no analfabeto o apetite de aprender está em sentir-se nivelado no direito político aos cidadãos intelectualmente superiores. (Apoiados). Dai preço ao voto: fazei 
dele instrumento de influência decisiva na sorte das administrações; ligai-o à instrução; ligai a ausência dela à privação dele; e, tornando o eleitorado uma posição, dignamente cobiçável, fareis cobiçar a instrução elementar ao menos, degrau legal para ele. (Apoiados). (BARBOSA, v. VI, t. I, 1945, p. 278)

Seus opositores respondiam, argumentando, que não havia escolas em quantidade suficiente, por isso, tal exigência mostrava-se descabida. José de Alencar (1991), em 1868, já discutia sobre a reduzida participação política do povo brasileiro, o voto censitário, a corrupção, a fraude e a ausência de partidos efetivos, demonstrando descontentamento com a forma de participação política adotada e apresentando elementos contrários aos defendidos por Rui Barbosa. Este respondeu, posteriormente, afirmando que a falta de acesso não poderia permitir que "pessoas ignorantes" pudessem votar, já que o direito ao voto poderia ser um estímulo para esse aprendizado. Para ele, o analfabeto não tinha como politizar-se, porque não lia jornais, meio fundamental para a formação cívica. Sem a leitura do conteúdo político veiculado pela imprensa - tema tratado no item seguinte - somente lhe restaria os mexericos da vila e a conversa fiada das esquinas.

A leitura, para ele, era responsável pela formação do cidadão e indispensável a um homem civilizado e moderno, tal posição foi disseminada ao longo do século XIX. O sufrágio universal era temido, uma vez que a imensa "maioria" constituída pelos trabalhadores, que já se organizava em sindicatos na Europa e erguia a bandeira socialista, poderia decidir a seu favor os pleitos eleitorais. O movimento revolucionário francês, de 1848, e a Comuna de Paris, de 1871, mostraram a força da classe operária, que pressionava para uma transformação social; a miséria da classe trabalhadora levava-a a reivindicar maior participação. Esta reivindicação levou à conquista do sufrágio universal na França e ao Estado caberia direcionar essa força social, ofertando uma educação homogênea, que difundisse questões de seu interesse, com vistas a formação de um cidadão ordeiro e dócil (MACHADO, 2002). Assim, crescia a campanha pela criação da escola primária gratuita, obrigatória e laica como espaço privilegiado para a formação para o trabalho e para o exercício de cidadania, era preciso orientar a massa trabalhadora para votar sem ameaçar os interesses burgueses ou a ordem estabelecida (LEONEL, 1994). Esta idéia repercutia no decorrer do século, encontrando adeptos desse lado do Atlântico, como o renomado americano Horace Mann, muito citado por Rui Barbosa. Escreveu esse americano, em 1846, que o ensino deveria ser custeado com recursos públicos:

[...] em um governo republicano, parece evidente que o mínimo dessa educação jamais deva ser menos do que o suficiente para habilitar esse cidadão aos deveres civis e sociais que terá de desempenhar; - educação que ensinará ao indivíduo as grandes leis da saúde do corpo; que o habilitará ao cumprimento dos deveres para com os pais; indispensável às funções civis de testemunha ou jurado; necessário ao eleitor nos negócios municipais; e finalmente conveniente ao desempenho fiel e consciente de todos os deveres que incumbem ao herdeiro de uma parte da soberania da grande república. (MANN, 1963, p. 77).

No decorrer do século XIX, propagou-se a idéia da necessidade de difusão do ensino primário sob responsabilidade do Estado. Esta questão é apresentada de forma enfática nos pareceres sobre educação, Rui Barbosa evidencia que a educação popular poderia solucionar um dos problemas que, segundo sua compreensão, comprometia o futuro do Brasil. Para ele, a formação da inteligência popular por meio da educação escolar era fundamental para a reconstituição do caráter nacional; levando o país à sua modernização, isto é, este deveria alcançar o mesmo estágio de desenvolvimento europeu, com todas as suas riquezas e misérias com todas as contradições próprias do capitalismo. Na Europa, a educação popular se colocava carregada de conteúdo político, buscando manter a unidade rompida com o acirramento da luta de classes e os avanços das idéias socialistas; diferentemente, no Brasil, levantou-se a bandeira 
em sua defesa, buscando mobilizar a criação de uma unidade que congregasse os homens para a modernização da sociedade. Fazia-se necessário forçá-los a produzir para o mercado mundial, por meio do trabalho assalariado. Para isso, seria fundamental ensinar ao escravo liberto a compreensão do valor do trabalho e instigar que participasse, como cidadão, dos negócios do Estado quando lhe fosse estendido o sufrágio universal.

\section{A abolição dos escravos e o projeto de emancipação dos sexagenários.}

Em meados do século XIX, intensificaram-se as discussões sobre o fim da escravidão e o destino dos libertos. Desde a década de 1830, havia uma forte pressão para o Brasil abolir a escravidão, criando mercado de trabalho para os miseráveis europeus e mercado consumidor para o excesso de produção das mercadorias industrializadas. Ela recebeu "um tiro certeiro" com a lei de 1850, que proibia, definitivamente, o tráfico de escravos. A seguir a Lei do Ventre Livre foi aprovada em 1871, libertando as crianças nascidas após essa data (MACHADO, 2004, p. 76).

Os escravos sexagenários foram declarados livres em 1884, contudo, a abolição completa ocorreria em 1888, contribuindo para a queda do Império. Na obra de Rui Barbosa, a questão da abolição dos escravos ocupou lugar importante, foi uma das principais questões discutida por ele dado o caráter de urgência com que se buscava modernizar o país. Ele participou na Câmara dos Deputados em defesa do projeto Dantas, que tratava da emancipação do sexagenário, em 1884, que não foi aprovado, tendo sido substituído pelo projeto que ficou conhecido como Lei SaraivaCotegipe de 1885. O debate em torno dessa questão mostrava-se feroz e agitava os ânimos da sociedade, para que ela chegasse ao fim em 1888, a luta foi árdua e longa, marcada por reformas graduais. Podemos acompanhá-la, em parte, por meio dos textos de Rui Barbosa que trataram desta questão, seja ao elaborar parecer na Câmara, seja na campanha realizada por meio da imprensa. Para ele, a transformação nas relações de trabalho era fundamental para civilizar o Brasil, este foi um dos últimos países a realizar a abolição. O trabalho livre desencadearia uma série de mudanças necessárias para o progresso do país, como a adoção da viação férrea, o incentivo à colonização mediante a imigração, o desenvolvimento da indústria, a criação de um sistema nacional de ensino, entre outras (MACHADO, 2002).

Segundo Rui Barbosa, a escravidão era o fundamento que sustentava a sociedade, “[...] era o alfa e o ômega da sociedade, que ela nutria, o alicerce, e, juntamente, a cumieira do Estado, que nela se incorporara [...]" (BARBOSA, v. XLVI, t. I, 1956, p. 78), mas o escravo era visto de forma pior do que um animal: "O escravo, pelo contrário, era, entre os companheiros do homem, o ínfimo dos sêres animados. Entre a humanidade e a animalidade, vegetava sem os foros de uma, nem as vantagens da outra, menos bem tratados que as alimárias de estimação, ou as crias de raça [...]" (BARBOSA, v. XLVI, t. I, 1956, p. 78).

A escravidão, na segunda metade do século XIX, estava sendo condenada mundialmente e, aos poucos, as colônias estavam libertando seus escravos. Binzer (1994, p. 99), uma professora alemã que viveu no país entre os anos de 1881 e 1884, discutia sobre essa questão e afirmava que "[...] todos os anos o Estado apresentava no orçamento um fundo de resgate; nas províncias, organizavam-se sociedades abolicionistas e muitos escravos tornam-se livres por iniciativa própria". Entretanto entenda que o problema não apresentava fácil solução. Rui Barbosa, em consonância com alguns contemporâneos, advogava a necessidade da abolição, mas enfatizava que ela não era o ponto final, apenas o ponto de partida para uma série de outras reformas. Ele entrou nesse debate para defender o governo, proferindo um discurso sobre o elemento servil em 28 de julho de 1884 (BARBOSA, v. XI, t. I, 1945). Em seu discurso, demonstrou que o Partido Liberal estava, há 16 anos, exigindo a abolição em seu programa, mas a questão não se encerrava apenas nesse partido, ela era uma questão nacional. Rui Barbosa, ao discutir o projeto de emancipação do sexagenário, mostrou que esta proposta procurava completar o movimento iniciado com a Lei do Ventre Livre de 1971 e responder às novas necessidades do país. 
Para ele, o projeto sobre a abolição do sexagenário não era novo e já era esperado na sociedade, contudo Rui Barbosa afirmou que não havia possibilidade da emancipação ocorrer "naturalmente". Isto exigia uma medida drástica. (BARBOSA, v. XI, t. I, 1945). Esse movimento favorável à abolição dos escravos cresceu na segunda metade do século XIX, esta era condenada por muitos autores, dentre eles destaca-se Joaquim Manuel de Macedo, que escreveu um livro intitulado As Vítimas Algozes - Quadros da Escravidão (MACEDO, 1991), em 1869, ilustrando a luta estabelecida entre senhor e escravo. Ele considerava que a abolição se colocava como uma exigência implacável da civilização e do século, todos aguardavam a solução para o problema da escravidão. Macedo colocou que a Inglaterra forçara o Brasil a proibir o tráfico em 1850, mas outras nações estavam exigindo a emancipação dos escravos, tornando-se difícil resistir por mais tempo.

Rui Barbosa, para polemizar a oposição provocada pelo projeto de abolição do sexagenário, recuperou a Lei do Ventre Livre e as dificuldades ocorridas para a sua aprovação. Todos acreditavam que, da forma como o governo queria realizá-la, representava a ruína da agricultura, teria como resultado "[...] a anarquia social e a miséria pública, com todas as suas desastrosas e incalculáveis conseqüências" (BARBOSA, v. XI, t. I, 1945, p. 67). Citou que Perdigão Malheiro temia uma insurreição geral. José de Alencar "[...] divisava no projeto 'uma grande calamidade social, que, sob a máscara da lei, ameaçava a nação brasileira'" (BARBOSA, v. XI, t. I, 1945, p. 68). Ele mostrou que a Lei do Ventre Livre não provocou bancarrota financeira (BARBOSA, v. XI, t. I, 1945, p. 76)

Para ele, o argumento de que o escravo era bem tratado era descabido, esse regime tolhia a liberdade do outro, bem como o trabalho assalariado dava melhores resultados, assim, considerava que os escravos libertos em outros países equivaliam a bons imigrantes e rendiam muito mais. Destacou que já se discutira muito que a escravidão "aviltava o trabalho" e que era uma das causas para a entrada de poucos imigrantes. A adoção do trabalho livre seria um estimulador para que o movimento colonizador se dirigisse para o Brasil de forma a resolver o problema da falta de mão-de-obra para a agricultura.

Para defender o projeto, Rui Barbosa, como um bom jurista, recorreu, também, à jurisprudência e à história parlamentar, concluiu que a lei civil herdada de Portugal nunca legitimou a escravidão. O Visconde de Jequitinhonha declarou que todos os fatos de sua vida pública mostraram que não era possível considerar a escravidão civil como um fato legal. $\mathrm{O}$ direito ao escravo como propriedade não era muito convincente e a indenização do liberto se colocava como questão polêmica. Discutiu a questão da indenização ou gratuidade, para este esta deveria ser apreciada pelo interesse público, pois o Estado não possuía recursos para indenizar todos os donos de escravo. Não era possível, entretanto, indenizar, mesmo porque após a libertação do escravo sexagenário, seria preciso chegar-se à abolição completa.

Rui concluiu que, no Brasil, a transição para o trabalho livre poderia ocorrer sem grandes conturbações, porque a população servil estava em proporção menor do que a livre. A população negra brasileira representava $1 / 12$ da população total. No país, estava se ramificando a indústria, encaminhava-se a imigração para algumas províncias e as experiências ensaiadas com o trabalho livre apresentavam resultados animadores. Com relação ao trabalho dos libertos, o projeto previa uma restrição moderada quanto ao direito de locomoção, impedia o escravo de residir em outro município por cinco anos e, a qualquer tempo, proibia a vagabundagem ao instituir a obrigação do trabalho. O código criminal previa meios repressivos contra a vadiagem, o que podia conter o ócio. O projeto não matava o interesse individual, o escravo trabalharia para ele mesmo. Assim, pode-se considerar intensa a participação de Rui Barbosa no debate sobre a emancipação do sexagenário e as dificuldades enfrentadas para a aprovação da Lei do Sexagenário em 1884.

O parecer de Rui Barbosa foi levado à discussão na Câmara em abril de 1885 e não foi aprovado. Dantas foi substituído por Saraiva, e a sua orientação, para Rui Barbosa, era menos avançada. Saraiva, um parlamentar conhecido e agricultor e senhor de escravos, apresentou um novo projeto no qual aumentava a idade do escravo de 60 para 65 anos, entre outras mudanças. $\mathrm{O}$ 
projeto de Dantas foi "sepultado nos arquivos" e o novo, aprovado com apenas 17 votos contrários. Essa lei foi assinada em 1885 por Saraiva e Cotegipe, seu sucessor.

Rui Barbosa fez muitas críticas a esse projeto fora do parlamento, visto que não conseguiu sua reeleição para a próxima legislatura, como exemplo, podemos citar a conferência A situação Abolicionista, proferida no Teatro Politeama, em 2 de agosto de 1885 (BARBOSA, v. XII, t. I, 1988). Entendia que o projeto de Saraiva oferecia, como resultado em dez anos, cem mil colonos, cinquienta mil alforrias sem ônus e oitenta mil liberdades condicionais. Em 28 de agosto, Rui proferiu novo discurso mostrando que o movimento abolicionista buscava apoio no exército. A escravidão era ainda questão fundamental, que não podia ser arrastada por muito tempo, ela encerrava em si todos os problemas sociais: "Mas, entre todos os problemas do nosso tempo, a questão das questões é a escravidão, - aquela a que todas as outras se subordinam, e encerra em si o começo de solução de todas as outras; a única que interessa, ao mesmo tempo, todos os princípios, todas as necessidades, no indivíduo, na associação, no Estado [...]". (BARBOSA, v. XIV, t. I, 1955, p. 74).

O governo, porém, mantinha-se indiferente. Assim, concluiu seu discurso implorando à rainha uma atitude em favor dos escravos. Em fevereiro de 1887, proferiu discurso no Comício do Teatro Recreio Dramático e tomou como tema principal os incêndios em canaviais em Campos atribuídos aos abolicionistas. No início do discurso, fez referência ao incidente entre governo e exército, posteriormente, criticou a polícia que indiciou os abolicionistas e os acusou de ter incendiado um canavial. Os abolicionistas saíram perdedores nesta acusação, já que sempre lutaram dentro da lei civil e a da caridade cristã. Fez, também, críticas a Cotegipe por permitir a utilização da delação para acusar o movimento de emancipação de maneira a abusar de seu poder, tais atitudes faziam o Império se envolver em nuvens e correr precipitadamente para a "noite".

Rui Barbosa publicou um panfleto intitulado $O$ ano político de 1887 (BARBOSA, v. XIV, t. I, 1955), no qual combateu o ministério conservador presidido por Cotegipe. No panfleto, discutiu o trabalho do Ministro da Fazenda, Francisco Belisário Soares de Souza, a doença do Imperador, a questão militar, criticou o trabalho da Câmara dos Deputados e a reação oficial ao abolicionismo. Criticou, além disso, um edital de 7 de agosto, que proibia o direito de reunião e os crimes por ele desencadeados. Os abolicionistas não podiam mais usar da palavra e isso levou os escravos a tomarem a questão em suas próprias mãos. Ocorreram evasões em massa de escravos agrícolas no município de Campinas e regiões vizinhas. Tornava-se difícil conter os escravos. A igreja e o exército saíram às ruas, favoráveis aos escravos, esses fugiram das fazendas, fazendo com que o governo se mostrasse incompetente para evitar a evasão. Instaurouse um estado de revolução. A abolição se colocava como questão de um, dois ou três anos. Rui acreditava que o momento levava à organização de uma nova era. Era preciso distribuir, socorrer, importar colonos para a agricultura e, depois, ver-se-ia o que fazer com os escravos, era urgente libertá-los.

No ano de publicação do panfleto, 1888, ele não estava, diretamente, envolvido com a abolição, para ele, ela já podia ser dada como resolvida com a subida de João Alfredo, membro do partido Conservador ao poder. Rui Barbosa se voltara para outras reformas, colocando a adoção do regime federativo como o principal problema a ser enfrentado. De fato, a abolição dos escravos aconteceu em 13 de maio desse ano, proposta pelo ministro do Império João Alfredo e assinada pela princesa Izabel, num curto documento que dizia estar abolida a escravidão em todo o país. Rui Barbosa criticou o fato de a monarquia ter deixado que os conservadores resolvessem a questão da abolição e que esta não era mérito da princesa, ela já estava imposta ao país. $\mathrm{O}$ único mérito da política regencial consistia em abrir os olhos à evidência.

Num discurso proferido após a abolição, no dia 19 de maio de 1888, Rui Barbosa registrou que se realizara uma das mais arrojadas transformações do país, esta poderia desencadear todas as outras. Era preciso reabilitá-lo, com a Monarquia ou sem ela, por meio de várias medidas, como a liberdade religiosa, a democratização do voto, o estímulo à adoção da 
pequena propriedade, a federação dos estados unidos brasileiros, "[...] com a coroa, se esta lhe for propícia, contra e sem ela, se lhe tomar o caminho" (BARBOSA, v. XVI, t. I, 1947b, p. 140).

Rui Barbosa continuou sua campanha contra a abolição fora do parlamento com o fim de seu mandato para Deputado e executou diversas tarefas. Candidatou-se, por duas vezes consecutivas, a um cargo na Câmara dos Deputados, em 1885 e 1886, mas não se reelegeu. Dedicou-se à advocacia, à imprensa e publicou a tradução de Lições de Coisas.

As experiências vividas por ele o colocavam num panorama geral marcado por transformações sociais, políticas, econômicas e educacionais no final do Império. Estas mantinham estreitas vinculações com o movimento do capital internacional, constituindo-se, assim, uma das faces particulares de uma mesma moeda. O país, objeto particular, deve ser estudado nas relações que estabelece com o movimento universal de crise do capitalismo. Este força a sociedade brasileira a modernizar-se, criando mercado consumidor para absorver o excesso de produção industrial que reverbera em superprodução, contrastando com o desemprego e a miséria da classe trabalhadora que fervilhava na Europa. Para conter esse turbilhão, que ameaçava abolir a propriedade privada e a apropriação individual do trabalho social dos assalariados com o crescimento do socialismo, a imigração torna-se "força civilizadora" desejada pelo novo mundo.

A sociedade brasileira mobilizava-se para a modernização capitalista, marcando o período imperial como de intensas transformações. Nele ocorreu a expansão cafeeira no oeste paulista, iniciou-se a imigração em escala crescente, ocorreu a Guerra com o Paraguai, nasceu o Partido Republicano, ocorreram tensões entre o Estado e a Igreja, entre o Estado e os militares, presenciou-se o avanço dos ideais positivistas, entre outros, que possibilitaram a Proclamação da República em 1889.

\section{O POLÊMICO JORNALISTA E SEU ENVOLVIMENTO COM A REPÚBLICA: O PAPEL DO ESTADO E DA IMPRENSA.}

Pela imprensa, Rui Barbosa discutiu muitas questões relacionadas com os problemas sociais do país, especialmente sobre a questão da libertação dos escravos nos anos de 1886 e 1887, dando continuidade ao que fazia como parlamentar. Nesse período, ele não era mais deputado, por não ter se reelegido, mas prosseguiu sua campanha abolicionista na tribuna jornalística, após a dissolução da Câmara. Em 3 de setembro de 1884, inicia a publicação de uma série de artigos no Jornal do Comércio (BARBOSA, v. XII, t. I, 1988). Rui escreveu 13 artigos, sob o pseudônimo de Grey, nos quais criticava as medidas políticas e econômicas tomadas pelo Governo Imperial. Para Athayde (1949, p. IX), Rui Barbosa reivindicava como de muito valor o título de jornalista, ponto culminante de sua carreira, e considerava-a como um importante veículo de divulgação de opinião. Escreveu: "Não há outra forma direta, leal e espontânea de comunicação com o público, ou meio mais eficaz para o apostolado político e religioso. Nem mesmo o tribuno falando pessoalmente aos grandes auditórios tem o poder de persuasão do jornalista, na intimidade que se estabelece entre ele e o leitor."

\section{Jornal Diário de Notícias - Queda do Império}

Sua mais famosa atuação se deu no jornal Diário de Notícias (BARBOSA, 1947b, v. XVI, t. I ao VIII), em 1889, quando escreveu como redator-chefe por um período de sete meses, estabelecendo um diálogo direto com o público ${ }^{8}$. Por meio de suas páginas diárias, criticava a lentidão demonstrada pelo Partido Liberal na execução de seu projeto político, ele se afastou desse partido em 1888 por discordar, particularmente, da política econômica adotada pelo Ministro da Fazenda, Visconde de Ouro Preto. Mas a sua aproximação com a defesa do regime federativo selou seu afastamento definitivo. Para Rui Barbosa, este era um ponto nevrálgico para a sociedade brasileira pressionada pela centralização do governo monárquico de maneira a 
impedir a modernização da sociedade, sua campanha ficou registrada no jornal Diário de Notícias, os seus artigos foram reunidos e publicados na Obra Completa de Rui Barbosa com o título Queda do Império (BARBOSA, v. XVI, 1947b), em 1921. Na sua introdução destacou como sua polêmica característica de estar sempre mudando de opinião sobre questões postas na sociedade brasileira, por isso recebia muitas críticas, e escreveu uma defesa interessante:

Pelo que toca ao variar das opiniões, deixem-me ter, mais uma vez, o consolo de trazer à praça como coisa de que me prezo, e não me pesa, a deliciosa culpa dos homens de consciência, a única em que hei-de morrer impenitente. Beata, beata, beatíssima culpa! Não mo tenham a mal os imutáveis. Deus os desencrue. Deus os reverta da pedra e cal em homens. Deus os ensine a mudar. Porque todo o aprender, todo o melhorar, todo o viver é mudar. De mudar nem mesmo o céu, o inferno ou a morte escapam. Mudar é a glória dos que ignoravam e sabem, dos que eram maus, e querem ser justos, dos que não se conheciam a si mesmos, e já melhor se conhecem ou começam a conhecer-se. (BARBOSA, v. XVI, t. I, 1947b, p. LXXXVI).

Nesses artigos, Rui Barbosa tratou de muitas questões, como os problemas vivenciados pelos moradores do Rio de Janeiro: o saneamento, o problema do beribéri na Marinha, o abastecimento de água na capital, o serviço de iluminação na cidade e o abastecimento de gás, entre outras. Não se eximiu, também, de criticar a Família Real, denunciando os incidentes que a envolvia com destaque para o endeusamento da princesa após a assinatura da Lei Áurea; a queda da Monarquia; a doença do Imperador e os Conselheiros da Coroa que a prejudicavam. Com profundidade, voltava-se para problemas políticos das mais diferentes ordens, como o direito de reunião, os incidentes entre monarquia e exército, a liberdade comercial, a reforma eleitoral, o casamento civil, a guarda negra, a centralização que tirava a independência do presidente da província, o senado brasileiro, a imigração artificial, o separatismo, entre outros (MACHADO, 2007).

Rui Barbosa defendia a necessidade de reorganização do trabalho assalariado após a emancipação dos escravos e mostrava a preocupação dos grandes proprietários de terras com a falta de mão-de-obra para a agricultura, sobretudo para a cultura do café. Destacava, nos seus artigos, a falta de incentivo por parte do Estado para a imigração e questionava a qualidade dos imigrantes recebidos. (BARBOSA, v. XVI, t. I, 1947b, p. 105).

O Ministério da Agricultura foi alvo de muitas críticas saídas de sua pena, já que a questão da imigração era polêmica e era urgente a necessidade de braços para o trabalho no campo. Para ele, isto só ocorreria se o "terreno" fosse preparado para recebê-lo, como a construção de via férrea, o estabelecimento de liberdade religiosa, política com facilidades na nacionalização, bem como reformas liberais na transmissão de terra e circulação dos títulos de propriedade, entre outras. O evento de 13 de maio, entendia Rui Barbosa, não encerrava a questão, ela significava apenas meia liberdade, sendo necessárias medidas voltadas para a adaptação dos libertos, como escreveu enfaticamente:

Declarar abolida a escravidão é dar apenas meia liberdade aos escravos. A parte mais difícil e mais importante da eliminação do jugo servil consiste na redenção intelectual do liberto, na sua educação para o regime da vida civil pela escola e pelo trabalho.

Instruir essa numerosa classe de cidadãos, e aparelhá-los para o trabalho inteligente são duas grandes necessidades, que o Estado não deve confiar exclusivamente à discrição das províncias. Há nessa aspiração elevadas conveniências nacionais, férteis em excelentes resultados. (BARBOSA, v. XVI, t. III, 1947b, p. 121-122). 
A educação tinha um importante papel na formação da nacionalidade brasileira, todavia as classes populares não recebiam nenhuma formação, equiparando os libertos à mesma sorte dos trabalhadores nacionais livres pobres. Sobre a educação dos libertos, escreveu no artigo de 24 de março de 1889, "Política de Paz":

Os riscos em que pode periclitar a condição dos remidos, não nascem da grande propriedade, absolutamente conformada, hoje, com a sua nova situação. Nascem deles próprios. São, posto que em grau diverso, os mesmos perigos comuns, entre nós, a todas as camadas populares: os perigos da ignorância e da inaptidão política.

Organizem os abolicionistas a educação dos libertos; e terão estes, antes dos filhos dos brancos, aquilo que os governos deste país ainda não quiseram dar à população brasileira; porque o ensino público decai sempre; e cada reforma, que se superpõe à rima das anteriores, é apenas uma transação entre a vaidade inculta dos administrantes e as ganâncias particulares dos administrados, neste gênero de negócio, o mais ímprobo dos que se exercitam entre nós. Promovam a reabilitação moral dos libertos pela instrução, como se faz, há vinte e cinco anos, nos Estados Unidos. (BARBOSA, v. XVI, t. I, 1947b, p. 170-171).

Criticava a educação brasileira ofertada em um número reduzido de escolas por ser insuficiente para atender à população brasileira, isso se agravava com a descentralização do ensino por muitas províncias, que não demonstravam nenhuma preocupação com essa questão. Todavia, na esfera política e econômica, sua posição era a de que a monarquia adotasse o regime federativo, a exemplo dos Estados Unidos (LUSTOSA, 2000). Outros autores já estavam lutando para limitar o poder central e combater o Ato adicional de 1834, como Tavares Bastos no livro "A Província" escrito em 1870: "Descentralizai o governo: aproximai a forma provincial da forma federativa; a si próprias entregai às províncias; confiai à nação o que é seu; reanimai o enfermo que a centralização fizera cadáver; distribuí a vida por toda a parte: só então a liberdade será salva". (BASTOS, 1975, p. 30).

Rui Barbosa retomou as críticas à Monarquia e defendeu a federação, sua posição levantou esse jornal e divulgou seu próprio nome, a partir daí criaria intimidade com o público, elevando o tom dos artigos e provocando o êxito editorial do supracitado jornal. Contudo, sua radicalidade o impedia de manter-se nas fileiras do Partido Liberal e o aproximava dos republicanos. Aproximou-se dos militares ao escrever artigos na defesa dessa classe e das medidas tomadas pela Monarquia. Para ele, o objetivo era dissolver o Exército e substituí-lo pela Guarda Nacional, destacando a necessidade de uma revolução. Em parte, a isto se deve o convite para participar da conspiração republicana. Sobre esta sua participação, Gonçalves (2000a, p. 58) escreveu que é "[...] É significativo que Rui, um republicano de última hora que até onde pôde se manteve fiel à Monarquia, estivesse, ao contrário de tantos republicanos históricos, na reunião crucial que determinou a queda do Império brasileiro. Ele acabou sendo [...] um dos principais braços civis do golpe militar que proclamou a República".

Após a Proclamação da República pela tropa comandada pelo general Deodoro da Fonseca, Rui Barbosa foi convidado a ocupar a pasta das finanças, já que, nas colunas do Diário de Notícias, opusera-se à política econômica de Ouro Preto. Como homem do Estado, poderia colocar em prática as reformas pelas quais lutara enfaticamente na última década. Defendera que a Monarquia mostrava-se inadequada à modernização em processo no país, instalara-se uma nova realidade econômica e social a partir de 1870 com a globalização do capital internacional, internamente crescia o movimento republicano como resultado da substituição do trabalho escravo pelo livre, do crescimento da imigração, da urbanização, do desenvolvimento de algumas indústrias e de um incipiente mercado interno. Assim, é possível afirmar que a República foi instalada como resultado da conjugação de diversas forças, sobretudo de uma parcela do exército e dos republicanos. Quando assumiu sua pasta no Ministério, fez uma 
exposição ao Governo Provisório para demonstrar a situação da Pasta da Fazenda, mostrando a necessidade de impulsionar o progresso. (BARBOSA, v. XVI, t. VIII, 1947b, p. 175 - 176).

A sociedade civil deveria livrar-se da servidão vivenciada no período imperial, o Estado assumiria importante papel. Como ministro, abandonou o lastro ouro, ampliou as emissões e alterou o regime das sociedades anônimas, provocando uma reviravolta completa na vida econômica do país. Ampliou-se, porém, o delírio da especulação, culminando com o encilhamento $^{9}$, o que o levou a receber muitas críticas. No início da República, dedicou-se, também, à questão do saneamento urbano e à redação da nova constituição como integrante da comissão encarregada de elaborar um ante-projeto a ser apresentado à Assembléia Nacional Constituinte (BARBOSA, v. XVII, t. I, 1946). Foi nomeado por um curto espaço de tempo vicepresidente da República. Nesse período, podem-se enumerar, ainda, como atos importantes: as eleições para a Assembléia Constituinte, o banimento da família real, a ação para separar à Igreja do Estado, consagrando-se a liberdade de culto e facilitou a naturalização dos imigrantes com o objetivo de criar uma nacionalidade brasileira ${ }^{10}$.

Sua política econômica encontrou opositores dentre os cafeicultores, desenvolveu a inflação e gerou uma crise no interior do Governo Provisório, da qual decorreu o convite para Rui Barbosa assumir a vice-presidência no período de dezembro de 1889 a agosto de 1890 (GONÇALVES, 2000a, p. 61) quando renunciou e foi substituído por Floriano Peixoto. Em setembro de 1890, Rui Barbosa foi eleito senador pela Bahia, mas suas atividades como ministro só se interrompeu em janeiro de 1891 com uma demissão coletiva dos ministros. O pedido de demissão coletiva pode ser atribuído à crise econômica do país, problemas pessoais de Rui Barbosa com Deodoro da Fonseca, à vontade de Deodoro de colocar, na Constituição, maiores poderes ao presidente e por uma crise geral de Deodoro com os ministros.

Após a sua demissão, o Presidente da República teve muitos atritos com os parlamentares e dissolveu a Câmara. Nesse momento, foi promulgada a Constituição republicana e houve eleições para Presidente da República, nas quais foram eleitos Deodoro da Fonseca como presidente e Floriano Peixoto como vice-presidente. O primeiro renunciou e Floriano Peixoto assumiu o governo. Contudo, ele não convocou nova eleição para presidente, ao contrário, decretou estado de sítio, levando muitos opositores para o desterro. Encerrado o estado de sítio, Rui Barbosa, como advogado, pediu habeas-corpus em favor dos perseguidos políticos ao Supremo Tribunal Federal, conseguiu anistia para todos os detidos e desterrados. A instabilidade reinava no país, eclodiu, no Rio Grande do Sul, a Revolução Federalista.

Pela imprensa, divulgou informações sobre os Estados Unidos e o regime federativo adotado na Constituição brasileira. Em 1892, reelegeu-se senador pela Bahia, havia renunciado ao mandato anterior, e assumiu a direção do Jornal do Brasil ${ }^{11}$ (BARBOSA, v. XX, t. II ao IV, 1949), no qual pedia eleição para presidente, contrapondo-se à ditadura de Floriano Peixoto. Este declarou estado de sítio em função da revolta da Marinha, Rui Barbosa foi identificado com os revoltosos e teve que exilar-se. Primeiro foi para a Argentina, transferindo-se em seguida para Portugal e Inglaterra.

\section{A volta do exílio e atuação no jornal $A$ Imprensa.}

Ao retornar a seu país natal, em 1895, reelegeu-se senador pelo seu estado - Bahia - em 1896. Rui Barbosa voltou-se para o jornalismo e publicou artigos no jornal A Imprensa ${ }^{12}$ até 1901. O jornal A Imprensa foi proposto por uma Sociedade Anônima, organizada pelo Sr. Carlos Viana Bandeira, em 30 de setembro de 1898, Rui Barbosa, como redator-chefe, escreveu o primeiro artigo em 5 de outubro desse ano, mantendo sua participação até 10 de março de 1901 . O jornal foi fechado em 15 de maio de 1901 e o seu material foi vendido para Edmundo Bittencourt, que fundou o Correio da Manhã. Lacombe $(1984$, p. 68) afirma que essa sua participação foi seu apogeu como jornalista, escreveu por volta de 600 editoriais. Para ele, Rui Barbosa se sentia atraído pela empreitada de jornalista porque via aí a possibilidade de atuar 
sobre o espírito do povo. Ele rejeitou a direção comercial desse jornal e assumiu um cargo técnico, o de redator-chefe. Cabia à secretaria a redação e preparação do jornal, a direção que imprimia à Imprensa se fazia por meio dos artigos enviados. Isto provocava constantes choques entre suas intenções e ações dos redatores. Alguns episódios provocaram pedidos de dispensa do cargo, que foram sempre recusados pela direção do supracitado jornal.

Rui Barbosa fazia questão de afirmar que esse jornal não se filiava a nenhum partido político. Segundo Lacombe (In: BARBOSA, v. XXV, t. I, 1979a), Rui Barbosa via na imprensa a "[...] possibilidade de atuar profundamente sobre o homem do povo". Para ele, ela "[...] era o modo mais eficaz de atingir a opinião pública". Nesse sentido, escreveu no primeiro editorial:

Embora as maiores instituições humanas se alienem, ou enxovalhem, resta-nos sempre uma, tão nova nos lábios de Gladstone como nos de Péricles: a instituição divina da palavra, capaz só por só de reconquistar todas as outras, quando associada à misteriosa onipotência da verdade. Tiraram-lhe a majestade da tribuna, pela qual os parlamentos governam. Mas ficou-lhe a imprensa, que se impõe aos governos, domina os parlamentos e instrui os povos. Considerada como órgão desta função, avulta incomparável, no mundo moderno, a sua grandeza. E é assim que a consideramos, que o seu prestígio fascina, que sua beleza nos deslumbra, que a sua missão nos atrai, que as temeridades, os sacrifícios, os perigos da sua comunhão nos acenam, ainda hoje, com uma sedução diversa, mas às vezes não menos viva que a de vinte anos atrás, quando o jornalismo arrebatou pela primeira vez no torvelinho a nossa mocidade. (A IMPRENSA, 1898, n. 1, p. 1).

A leitura diária do jornal poderia informar à população sobre as questões mais candentes da sociedade brasileira. Rui Barbosa se referia à imprensa como um "instrumento de educação nacional", colocava ser necessário encarar "[...] a imprensa como uma escola, um magistério, a cultura cotidiana do espírito público, ministrada sob o voto de professar a verdade, insinuar o belo, advogar o bem". (A IMPRENSA, 1898, n. 1, p. 1). Cada "jornalista" assumia o papel de um professor, mestre de primeiras letras e, ao mesmo tempo, um catedrático da democracia em ação, por fornecer o pão do dia, as primeiras lições, as primeiras idéias para formulação de posicionamentos sobre os problemas econômicos, políticos, sociais e culturas.

Rui Barbosa valorizava a imprensa como um espaço privilegiado, porque ela teria o poder de desmoralizar rapidamente as pessoas. Comentava que este veículo de comunicação não podia ser invadido pelo comércio, levando esse periódico a se degenerar e industrializar-se, conforme o modelo dos jornais que divulgavam sensacionalismos à americana. Assim, somente idolatrar-se-ia à notícia, cultivando o escândalo e a exploração dos baixos apetites da curiosidade, levando a autoridade da imprensa ao descrédito. Desta forma, um bom jornal deveria contribuir para formar opiniões e discutir questões importantes para o país.

No que se refere às questões educacionais, o jornal trazia artigos específicos, podemos citar o do dia 19 de novembro de 1898, intitulado "Lentes de Medicina", e o de 6 de dezembro desse mesmo ano, "O Internato do Ginásio". No ano seguinte, ainda em primeira página, escreveu um artigo "A oração do Paraninfo" (07/02/1899) e "Instrução Naval”. Ao lado desses artigos, o jornal noticiava, por exemplo, a Reforma na Escola Militar, que propunha a supressão da cadeira de biologia, sociologia e moral, equiparando o salário ao dos docentes da Escola Naval. Incluía artigos do Jornal Mineiro, criticando o Projeto de Lei que passava o ensino superior para a responsabilidade dos estados. Ao mesmo tempo, informava sobre mudanças na legislação educacional. No dia 18 de março de 1989, o jornal publicou parte do novo regulamento da escola naval, continuando nos próximos números. Pelo jornal, tinha-se acesso aos resultados dos exames efetuados na Faculdade Livre de Direito, às festas de colação de Grau dos bacharelandos de São Paulo e sobre a Faculdade Livre de Direito. 
Rui Barbosa apresentava suas opiniões por meio do jornal diário; como redator-chefe, posicionou-se sobre diversas questões, como a política governamental e problemas cotidianos, como o saneamento e a urbanização da cidade do Rio de Janeiro. Para tanto, discutia o abastecimento de água, o fornecimento de gás, a iluminação pública utilizando a força elétrica, a incineração do lixo, o serviço telefônico, entre outros. Além desses problemas, voltou-se para o questionamento dos monopólios, das taxas alfandegárias, da cobrança de impostos, da liberdade de comércio, do voto do estrangeiro e do papel do Estado nessa sociedade. Este deveria intervir nos casos em que a concorrência fosse impossível ou prejudicasse o interesse comum. Esta idéia era reiterada nos artigos em que discutiu, especificamente, as questões educacionais. Como se encontrava a educação naquele momento? Veríssimo (1985, p. 29) afirmou que, depois de 24 de fevereiro de 1891, “[...] as leis e regulamentos que regiam aquelas duas espécies de ensino e os institutos que aqui no Rio de Janeiro e em alguns Estados o distribuíam, tudo na realidade continuou como dantes. Ou, mais exatamente, piorou. Não podia ser maior [...] o desinteresse dos poderes públicos por esta sua função de velar pela educação nacional [...]". Contaminado por essa atmosfera e buscando defender o ensino público pelo jornal, Rui Barbosa publicou o artigo "Lentes de Medicina" (BARBOSA, v. XXV, t. II, 1979a), no qual criticou o Projeto de Lei que reduzia vantagens de salário dos professores. Efetuou a seguinte denúncia:

Melhor é prevenir do que remediar, e é prevenindo, muitas vezes, que deste lugar se prestam os melhores serviços ao país. Vem o abuso amostrando a ponta da unha, dá-lhe o jornalista em cima com o bom senso, ou a lei, e ei-lo que recolhe incontinente a garra. Surde o erro a furta-passo, tenteando a coragem de assoalhar-se francamente; mas a imprensa, que o pressentiu, dá-lhe o rebate da censura, que o espera, e já não há mais que o recear. É uma das suas maiores utilidades esta função preventiva da imprensa. Vale talvez mais do que os seus meios de repressão; porque muito mais difícil é remover o mal feito, e o corretivo da crítica, em relação a medidas adotadas, tem de lutar com o amor próprio dos homens do poder, empenhado na defesa das suas obras.

São reflexões, que nos sugere a notícia do intuito, atribuído à comissão de orçamento na câmara dos deputados, quanto aos vencimentos no magistério nas escolas de medicina. (BARBOSA, v. XXV, t. II, 1979a, p. 139).

Com este comentário, criticava a Lei disposta no artigo 295 do Código do Ensino Superior, que prescrevia a correção dos salários dos lentes catedráticos, substitutos, professores e secretários. Estes, ao cumprirem suas funções, teriam, periodicamente, o direito a um acréscimo de vencimento (BARBOSA, v. XXV, t. II, 1979a, p. 140). Considerava indigno os salários recebidos por estes professores, dada a relevância do trabalho executado, caso não se corrigisse seus proventos, o magistério seria tomado por indivíduos sem conhecimento e preparo para o exercício dessa tarefa. Rui Barbosa (v. XXV, t. II, 1979a, p.143), para concluir seu raciocínio, escreveu que o "Estado não tem direito de exigir serviços que não pague; e, se os não pagar, ninguém, numa democracia, onde as classes competentes são pobres, lhos prestará seriamente".

Entendia ser importante revitalizar o ensino, em particular ofertando escolas para as classes populares, questão amplamente debatida por ele na Câmara dos Deputados durante o período Imperial. Veríssimo (1985, p. 53), ao referir-se à decadência do ensino no país no período republicano, também denunciava o descaso para com a educação: "O nosso sistema geral de instrução pública não merece de modo algum o nome de educação nacional. É em todos os ramos - primário, secundário e superior - apenas um acervo de matérias [...] e estranho completamente a qualquer concepção elevada de pátria”.

Apesar de sua importância, anunciada por intelectuais como o citado anteriormente, afirmava Rui Barbosa, por meio de A Imprensa, que a educação nenhuma atenção estava recebendo do novo governo, como exemplo, citou a inexistência de escolas secundárias para as classes populares. Agravaria, no seu entendimento, as condições de ensino ofertadas se 
acontecesse o fechamento do internato, como colocado, por reforma educacional. Sob tal ameaça, escreveu o artigo "O internato do ginásio" (BARBOSA, v. XXV, t. III, 1979a, p. 63), referindo-se ao Ginásio Nacional, antigo Colégio Pedro II. Ele se mostrava favorável a essa instituição de ensino, sendo possível, no seu entendimento, descrever vários benefícios oferecidos à população por estes estabelecimentos. Nessa escola, havia menores sem família e com falta de condições sociais para completar em casa as tarefas escolares. Esta era a única forma de escolarização dos pobres, visto que o ensino secundário estava monopolizado e acessível à elite, que podia custear seus estudos. Rui Barbosa não deixava de considerar as condenações que se faziam aos internatos à medida que os jovens eram separados da sociedade, permanecendo sem contato social. Contudo, apesar dos problemas decorrentes desse isolamento, era importante a formação escolar ali recebida, já que os desvalidos não teriam outro meio para receber sua formação.

Outra questão que incomodava Rui Barbosa era o definhamento dos recursos públicos destinados à educação. Em especial, no artigo "Oração do Paraninfo", ao comentar sobre o discurso pronunciado por Francisco de Castro na colação de grau dos doutorandos em medicina, em 3 de fevereiro de 1889, publicado na íntegra no supracitado jornal em 7 de fevereiro do mesmo ano, discutiu o descaso do governo republicano para com o ensino. Destacou a questão do discurso do citado orador que denunciava o descaso do governo para com o ensino superior. (BARBOSA, v. XXVI, t. III, 1954, p. 252-253).

Rui Barbosa criticou os projetos legislativos que apenas estimulavam a desorganização e morte do ensino oficial. Ressaltou que esta sua crítica não era ao Legislativo, visto que este salvara o país da ditadura de Floriano Peixoto. Os defensores da não-subvenção do Estado na educação recorriam aos textos de Spencer e Comte, nestes autores, os políticos obscurantistas encontravam as melhores armas para fundamentar seus argumentos. Em Estática Social, existia um capítulo inteiro contra a interferência do Estado na instrução pública, vedando-lhe, também, a ligação com a religião e a caridade. Contrapondo-se a esses argumentos, Rui Barbosa afirmava ser os escritos de Stuart Mill mais adequados ao momento pelo qual o Brasil passava. Assim, comungava com este autor de que a interferência do Estado em matéria de ensino era justificável, já que, neste assunto, não era possível que o interesse e o critério do consumidor garantisse a excelência do produto. Assim, a relação do Estado com a religião era muito diferente da sua relação com o ensino. A citação abaixo, embora longa, apresenta os argumentos de Rui Barbosa:

Aos olhos da abstração inflexível interpor-se o Estado ao curandeiro e o cliente, que o consulta, ao farmacêutico e o freguês, que se lhe reclama uma aplicação clínica, é infringir os direitos do indivíduo, transgredir a lei moral. Vá o enfermo buscar a cura nas mãos de quem lhe pareça; exerça o facultativo licenciado por si mesmo a medicina entre os que o buscarem. O uso dessas profissões é meramente questão de liberdade comercial. Deve ser regulada pelos mesmos cânones da oferta e da procura. Se ao Governo não pode caber a tutela sobre a higiene moral das almas, tão pouco lhe pode tocar a inspeção da higiene física nos estados. Não se melhora a saúde pública por atos do parlamento. Tributar o povo, a fim de sanear as cidades, impor condições de idoneidade ao exercício de uma profissão, cujos erros topam a cada passo na morte, é violar a liberdade nos seus reclamos essenciais.

Eis a escola spenceriana, a mesma, neste assunto, do positivismo, cuja filiação aliás nem SPENCER, nem MILL, nem HUXLEY aceitam. Esse excepcional engenho de COMTE, cujos erros encontraram formidáveis dissectpores (sic) nos três sábios ingleses, comunicou ao ânimo dos seus alunos, cujo peso a República, no Brasil, ainda não cessou de sentir, figadal inimizade ao ensino oficial. (BARBOSA, v. XXVI, t. III, 1954, p. 255) 
Rui Barbosa discutia, nesse artigo, a necessidade de uma nova configuração para o Estado. Questionava assim, o Estado burguês definido, em 1690, por Locke (1983, p. 34) como aquele com a função principal de garantir a propriedade privada: "Considero, portanto, poder político o direito de fazer leis com pena de morte e, conseqüentemente, todas as penalidades menores para regular a propriedade, e de empregar a força da comunidade na defesa de dano exterior, e tudo isso tão só e prol do bem público.

Essa definição do liberalismo inglês seria detalhada quase um século depois por Adam Smith (1998), este, ao defender a liberdade de produzir e trocar mercadorias sem nenhuma interferência por parte do Estado, procurou explicitar a necessidade de sua "mão invisível". A este caberia assegurar condições para os homens, no mercado livre, exercitarem a sua propensão natural para a troca. Deixe fazer e deixe passar eram palavras de ordem no ataque às relações servis que sustentavam a sociedade feudal. A igualdade e a liberdade adquiriram um significado particular ao oferecer condições para o desenvolvimento da sociedade burguesa. Esta sociedade surgiu da decadência do modo de produção anterior, incapaz de reproduzir sua forma de ser enquanto produzia apenas para a subsistência.

No reino da "liberdade", as novas forças produtivas sociais possibilitaram o crescimento da produção, dissociando os trabalhadores dos meios de produção, colocando-os em condições de submeterem-se as relações de assalariamento. Esses trabalhadores expulsos do campo se aglomeravam nas cidades e constituíram o mercado interno, necessário para o estabelecimento de relações capitalistas no campo. Estavam criadas as novas relações sociais fundamentadas na produção social dos trabalhadores coletivos, especialistas em uma atividade específica da manufatura e na apropriação capitalista, individual, do produto final. Essa nova força social produziu uma revolução sem precedentes que culminou em crises cíclicas no século XIX, a massa miserável de trabalhadores e de desempregados se insurgia contra a exploração capitalista; greves, revoluções e reivindicações colocavam o socialismo como tema ameaçador. Para conter esse movimento, a Democracia revelava-se como possibilidade de conciliação entre as classes, pois possibilitaria um novo estatuto de igualdade: todos os indivíduos tornavam-se cidadãos votantes, conquistava-se, desse modo, igualdade jurídica e não igualdade material. Para conter a crise, o Estado assumiria uma nova configuração, tornando-se conciliador, interferindo em alguns setores da economia para fomentar a continuidade de produção de mercadorias. Ao mesmo tempo, era chamado para tornar-se Educador, com o objetivo de educar as massas de forma que estas não ameaçassem a sociedade burguesa. Na Europa, a força da classe trabalhadora deveria ser controlada e dividida, sua imigração para novas terras era uma necessidade. O Brasil, ainda em processo de industrialização, precisava de mão-de-obra e de capital para sua modernização.

Nesse processo, o Estado assumiria novas atividades e cresciam os defensores da sua intervenção em algumas esferas. Intelectuais, como Rui Barbosa, defendiam a sua interferência para garantir ordem e prosperidade e, acima de tudo, garantir a propriedade privada. Para tanto, era preciso que os intelectuais, com visão ampla, esclarecessem a população para a necessidade de modernização e de superação da situação de ignorância da população pobre, incapaz de reconhecer e buscar, por si só, alternativas de mudança e se submeterem ao trabalho assalariado que se organizava após a abolição do trabalho escravo. Rui Barbosa, nesse contexto, defendia que a educação oficial era importante, ao lado de outras reformas, para a construção do Estado Nacional almejado. O trabalhador livre nacional e pobre precisava da escola para ensinar-lhe a votar acertadamente e a amar o trabalho. O trabalhador imigrante deveria ser integrado na nova nacionalidade, para tanto, a língua nacional, a geografia e a história do Brasil tornavam-se conteúdos fundamentais. Concordava com a nova função do Estado de financiar a escola pública e criticava a ação do governo brasileiro nos níveis primário, secundário e superior. Para reafirmar suas críticas à situação do ensino brasileiro, em artigo 27 de maio de 1899, discutiu a situação do ensino profissional e a falta de instrução prática oferecida aos guardas-marinhas. $\mathrm{O}$ artigo intitula-se "Instrução naval" (BARBOSA, v. XXVI, t. V, 1979b, p. 135-142). Ele se 
voltou para todos os níveis de ensino, criticando a inexistência de um Ministério da Educação que organizasse um sistema nacional de ensino no Brasil. Acreditava que, as reformas educacionais pontuais em nada contribuíam para melhorar o ensino e atender às necessidades postas com o processo de modernização desencadeado no país com a passagem do trabalho escravo para o livre, do Império para a República e de uma economia agrícola de monocultura para uma industrialização incipiente.

Ao fazer um balanço da atuação de Rui Barbosa como jornalista, Cardim (1995, p. 706) escreveu que sua atuação no jornal "A Imprensa" foi seus últimos feitos como jornalista e conclui: “[...] A vida jornalística de Rui Barbosa foi tão notável quanto a sua vida de advogado e jurista e a sua vida parlamentar e de homem do governo [...]".

Em 1902, deixa de escrever no jornal A Imprensa. No Senado, foi eleito como relator da Comissão Especial do Senado incumbida de estudar o Projeto do Código Civil, emitiu um parecer criticando a linguagem dos artigos, propôs ementas para muitos artigos e discordava da pressa pela qual buscavam realizar a tarefa. Em 1903, participou das discussões sobre os limites entre o Brasil e a Bolívia, os quais disputavam o território do Acre. Rui Barbosa se exonerou do cargo por discordar dos encaminhamentos dados por Rio Branco, ministro das Relações Exteriores. Após a resolução desta questão, assumiu, como advogado, a causa movida pelo estado do Amazonas contra o Brasil, requisitando aquele território.

\section{O “ÁGUIA DE HAIA" E AS CAMPANHAS PARA PRESIDENTE DA REPÚBLICA.}

Rui Barbosa foi convidado pelo presidente Afonso Pena, em 1907, para ser o representante brasileiro na Segunda Conferência da Paz, realizada em Haia na Holanda. A tarefa da Conferência, que reunia 48 países, era "[...] resolver amistosamente os litígios entre as nações e atenuar os efeitos da guerra sobre os combatentes e aqueles que forem afetados indiretamente por ela. RB, com poderes especais, assina a ata de adesão à Convenção de 29/07/1899 para o concerto pacífico dos conflitos internacionais.”(FUNDAÇÃO..., 1995, p. 127). No final do século XIX e início do XX, o continente europeu viveria em clima de vigilância permanente, muitos conflitos indicavam a possibilidade de guerra entre nações. Crescia a competição econômica entre as nações, o que favorecia rivalidades por conquistas de novos terrítórios e mercados para absorver os produtos industrializados e as indústrias, por sua vez, desenvolviamse a todo vapor. Como conseqüência, evidenciava-se a disputa militar entre as nações ampliando os gastos com armamentos, decorrendo, daí, a acentuação da crise de cada país individualmente e o aumento do risco de guerra. Sobre este período, Hobsbawm (1995, p.16) escreve sobre o colapso vivido nesse momento e o fim dos ideários liberais burgueses:

Ele começa com a Primeira Guerra, que assinalou o colapso da civilização ocidental do século XIX. Tratava-se de uma civilização capitalista na economia; liberal na estrutura legal e constitucional; burguesa na imagem de uma classe hegemônica característica; exultante com o avanço da ciência, do conhecimento e da educação e também do progresso material e moral; e profundamente convencida da centralidade da Europa, berço das revoluções da ciência, das artes, da política e da indústria e cuja economia prevalecerá na maior parte do mundo $[\ldots]$.

As duas Conferências, de 1898 e de 1907, buscavam preservar a paz. O Brasil não enviara representante para a primeira, mas marcou presença na segunda. Buscava-se conter a militarização e armamento dos países, bem como resolver os problemas pela diplomacia, o que exigiu a criação de uma corte permanente de arbitramento. Apesar destas tentativas, a guerra aconteceu em 1914. A participação de Rui Barbosa, contudo, foi polêmica e contribuiu para divulgá-lo como um mito. Costumeiramente, é descrita, pelos biógrafos e comentaristas, com muitos louvores ${ }^{13}$, ficou conhecido, posteriormente, como “Águia de Haia”. 


\section{Campanha Civilista - 1909.}

Não menos importância têm, em sua obra, as campanhas políticas das quais participou, uma no ano de 1909, quando foi candidato à presidente da República ${ }^{14}$, disputando o pleito com Hermes da Fonseca, outra em 1918, concorrendo com Epitácio Pessoa, que obteve a maioria dos votos. Esta disputa ficou conhecida como Campanha Civilista. O presidente em exercício sempre tentava indicar seu sucessor, Afonso Pena queria fazer essa indicação e buscou se reconciliar com Rui Barbosa, que não quis nenhuma aproximação. Embora tivesse por diversas vezes servido aos interesses das oligarquias na realização de seus ideais políticos, tais oligarquias eram hostis à sua visão política de construção de um Brasil moderno e democrático. Segundo Fausto (2003), os "coronéis" controlavam os votos na sua área de influência, trocando os votos por favores, como par de sapatos, vaga em hospitais e empregos. O voto era em aberto o que facilitava o controle do voto, Rui Barbosa já denunciava a necessidade de adoção do voto secreto, já realizado em alguns países democráticos.

Num jogo político complexo, Rui Barbosa afirmava só sair candidato oficial se houvesse um movimento nacional a seu favor, defendendo como proposta primeira de sua plataforma a revisão da Constituição, a qual pretendia moralizar o processo das eleições, idéia temida pelos grandes proprietários. Os militares, por estarem descontentes com os governos civis, lançaram a candidatura do marechal Hermes da Fonseca, sobrinho de Deodoro da Fonseca, tendo como vice Venceslau Brás. Rui Barbosa, contudo, não deu apoio a essa chapa, mostrando-se contrário à ocupação de cargos políticos pelos militares, defendia que só poderiam fazê-lo se os ocupassem como cidadãos, o que não era o caso. A candidatura de Hermes representava, no seu entendimento, uma intervenção militar. Na convenção de agosto de 1909, Rui Barbosa e Albuquerque Lins, então governador de São Paulo, saíram como chapa dos dissidentes. Tinham apoio de parte da oligarquia paulista e baiana, em princípio. Sobre essa candidatura Gonçalves (2000a, p. 120) escreve:

Diante de todos esses antecedentes de disputas e alianças oligárquicas, é espantoso que a campanha de Rui Barbosa pela presidência da República se tenha tornado uma das grandes páginas da construção da democracia no Brasil e um dos eventos mais importantes do combate ao domínio oligárquico na Primeira República. De um ponto de vista histórico mais amplo, foi a primeira vez em que realmente se disputaram eleições para a chefia do Estado brasileiro. Não resta a menor dúvida de que o conteúdo antioligárquico que a campanha tomou estava em nítida contradição com o apoio recebido das oligarquias paulistas, baiana e, mais tarde, da fluminense. Sem poder correr sozinho, Rui optou por lutar pela democratização do país, aliando-se com setores temporariamente dissidentes da máquina política. Ele instrumentava politicamente o próprio inimigo para trazer-lhe a seu lado.

Pode se dizer que a primeira característica democratizante da campanha (que logo se chamou de civilista por se opor a um candidato militar) foi sua própria forma. Levar a cabo uma autêntica campanha política - promovendo debates em torno de programas e ideias, tentando persuadir o eleitor pela palavra e pela razão - já era uma grande inovação nas práticas políticas de então. A bem dizer, era uma verdadeira subversão dos costumes políticos.

Nessa campanha, Rui Barbosa proferiu oito conferências, fez 15 discursos e proferiu 10 alocuções ${ }^{15}$. Realizou, ainda, excursões pelo país, levando o povo a se reunir em teatros e praças públicas. Seu programa básico consistia na denúncia da volta do terror militar, da necessidade da consolidação da ordem civil e da revisão constitucional, com destaque para a alteração da forma de governo (Parlamentar ou República), a adoção do sufrágio universal. Discutiu sobre a situação das oligarquias, sobre a justiça, o código civil, a instrução pública, a religião, a questão 
financeira, a imigração, a fiscalização aduaneira, a organização do Distrito Federal, o Exército, a Marinha, entre outras questões.

Rui Barbosa buscava incentivar o crescimento e o investimento do país em diversos setores, para o país não desenvolver apenas a produção cafeeira. Para tanto, era necessário o estímulo à iniciativa individual para que surgissem outras culturas, atraindo homens de competência prática. O Estado deveria ter uma legislação para assegurar os contratos e favorecer uma maior liberdade das fronteiras para facilitar o comércio. Destacava a necessidade de reformas para evitar revoluções, solicitando flexibilidade das idéias em face das mudanças. Assim justificava sua forma de pensar:

[...] como acredito, que ainda mais importante do que a estabilidade, num sistema de governo, é a sua ductilidade em se reformar sem Revoluções. Seria do melhor agoiro para as nossas instituições que os espíritos realmente conservadores e os nossos homens de responsabilidade não continuassem a tapar os olhos a este rudimento de senso político, onde reside o segredo fácil da longevidade para todas as Constituições livres (BARBOSA, v. XXXVII , t. I, 1967, p. 42).

Para implementação de suas propostas, acreditava que, na reforma constitucional, deverse-ia assegurar o direito de votar a todos. Na Constituição de 1891 (BARBOSA, v. XVII, t. I, 1946), o direito do voto era garantido aos brasileiros, inclusive aos naturalizados, maiores de 21 anos, excetuando-se analfabetos, mendigos, soldados e religiosos sujeitos às obediências eclesiásticas. Assim, a partir dessa Constituição, Rui Barbosa sugeriu mudanças, acreditava ser necessário que, aos 21 anos, a pessoa tirasse o título de leitor, expedido pelo juiz mediante a apresentação de um documento pessoal e a prova de saber ler e escrever. Defendia que, além do sufrágio universal, entendido como a não-comprovação de renda, já que os analfabetos e mulheres não tinham direito ao voto, era preciso que o voto fosse secreto. $\mathrm{O}$ voto em aberto obrigava o eleitor a revelar, publicamente, o seu candidato, possibilitando aos grandes fazendeiros pressionar no momento da votação. Segundo Assis Barbosa (1981, p. 13):

Das eleições do Império, João Francisco Lisboa dizia que espalhavam “o espanto e o terror". Na República, a ata falsa acrescentara à violência a patifaria. As eleições se faziam mais nas atas que nas urnas. Havia especialistas na matéria. Enchiam bandas e bandas de almaço num paciente exercício de caligrafia, com a caneta enfiada sucessivamente entre os dedos da mão direita, para repetir em seguida os mesmos golpes de habilidade com a mão esquerda.

Verifica-se, nessa campanha, a preocupação de Rui Barbosa para com a liberdade do voto e da necessidade de educar para o voto, mostrando uma posição semelhante à assumida em 1881 quando defendeu o voto censitário e a exclusão dos analfabetos. Acrescentou, também, a necessidade de proporcionalidade do voto para que as minorias tivessem representação, contrapondo-se ao voto cumulativo.

Na plataforma de governo, buscava esclarecer dois conceitos errados sobre a função do Estado em matéria educativa no seu entendimento. Para uma corrente, era legítimo que o Estado ensinasse, contudo, ele defendia que, sua tarefa era remunerar, nomear, animar, sustentar, sem dirigir totalmente o ensino. A direção deveria ser dada pelas corporações, constituídas por profissionais competentes. Desse modo, o Estado não ensinava, uma vez que seu papel era criar e manter o ensino. Outra corrente defendia que o Estado ensinasse a "ciência feita". Rui Barbosa achava que isto não existia, a ciência não poderia ser dada por acabada, muitas ciências estavam em construção. A verdadeira ciência, afirmava, era aquela que combinava observação e raciocínio, descobrindo leis para explicar os fenômenos. Era preciso demonstrações por meio de 
averiguações, classificação e explicação. O que não se pudesse conhecer, deveria ser considerado inverificável.

Durante essa campanha, no teatro Politeama, na Bahia, colocou que o seu entendimento sobre a instrução pública havia sido exposto quando da redação dos pareceres, eles continham aspectos modernizadores e civilizadores, semelhantes às características de sua atual campanha política, cujo objetivo era ampliar a participação do povo na escolha do presidente. Ele destacou que as questões apresentadas não poderiam ser ignoradas, porque pouco havia sido realizado na divulgação da escola pública. Novamente, procurava reunir autoridades, profissionais liberais, intelectuais e o povo, em especial, para dividir seu sonho pela democracia e o exercício da cidadania. A educação era um importante elemento de conscientização da sociedade, inclusive para a incorporação dos imigrantes à nacionalidade brasileira.

Rui Barbosa organizou sua proposta sobre educação em cinco pontos, como apontado por Beviláqua (2003): melhorar o ensino secundário nos estabelecimentos federais; reformular o ensino jurídico, dando mais atenção à sua prática e a um espírito mais científico; adoção de aulas práticas nas escolas de medicina, desenvolvendo mais gabinetes e laboratórios; obrigação ainda maior quanto à freqüência escolar; e criação de uma universidade no Rio de Janeiro como as da Alemanha. Em síntese, sua proposta nessa campanha, enfatizava, iria além de uma instrução que ensinasse a ler e a escrever, deveria passar, também, pelo modo de agir da sociedade, desde o exemplo dos juristas e parlamentares até que o povo percebesse que havia uma nova postura com relação às funções públicas. Em sendo eleito, implantaria as mudanças apontadas em função da situação financeira do Estado.

Ele obteve maioria de votos nas grandes cidades, todavia perdeu no interior do país. Nessas campanhas, Rui Barbosa deixou expresso o projeto que visualizara para o Brasil. Para Lacombe (1984), sua campanha foi em vão, visto que a máquina política foi usada com abuso, o mandonismo e a fraude decidiram o pleito. Hermes da Fonseca saiu vitorioso. Francisco de Assis Barbosa (1981) enfatiza que a campanha foi decidida nas atas e não nas urnas. Para ilustrar o ocorrido no processo, evidencia os mesmos sinais caligráficos nas assinaturas, revelando que a fraude havia sido realizada até por pessoas semi-alfabetizadas e a enorme quantidade de eleitores fantasmas.

Rui Barbosa representou o Brasil durante as comemorações da Independência da Argentina em 1916, foi convidado pelo governo de Venceslau Braz para ir à Argentina como embaixador. Em uma conferência intitulada "O descer dos neutros", na Faculdade de Direito de Buenos Aires, discutiu a necessidade de os países não se manterem neutros frente aos acontecimentos da Grande Guerra (1914-1918). Sua conferência causou impacto naquele momento e, em função dessa sua posição, participou de uma manifestação popular contra a agressão alemã a navios brasileiros e foi chamado pelo presidente Venceslau Brás para uma reunião na qual decidiu-se revogar a neutralidade do país na guerra. Para ele, a Guerra poderia permitir a consolidação da democracia nos países envolvidos, uma vez que a democracia venceria os governos autoritários inimigos. Comemorou, também, a Revolução Russa de 1917, que derrubou o absolutismo czarista em nome da democracia, contudo, logo foi suplantada pela Revolução Socialista, que mostrava o avanço e a força da classe operária internacionalmente. No Brasil, a primeira greve geral deixou todos em alerta, trazendo para a cena do dia os debates sobre as questões operárias. Dois anos depois, disputou, novamente, a presidência da República, na qual a questão social e política foi a tônica de sua campanha.

\section{A Campanha de 1919 e a questão social.}

Em 1918, foi comemorado o Jubileu Cívico de Rui Barbosa, seguido da inauguração de seu busto na Biblioteca Nacional. No ano seguinte, novamente, concorreu à presidência do país, o pleito fora disputado com Epitácio Pessoa, que saiu vitorioso. Apesar desse resultado, sua campanha foi curta, mas intensa: "Reduziu sua propaganda basicamente a cinco conferências: 
duas no Rio, em março; uma em Juiz de Fora, outra em São Paulo e a última em Salvador, todas em abril. Em sua terra natal, onde a 13 desse mês assistiu ao pleito, foi recebido com verdadeiro delírio popular" (GONÇALVES, 2000a, p. 157).

Em sua campanha, discutiu um programa de direitos sociais, cujo objetivo seria melhorar a situação dos trabalhadores brasileiros. A Revolução de outubro de 1917 na Rússia provocou espanto em Rui Barbosa, este via na ameaça socialista a destruição dos direitos individuais e de liberdades, atento às reivindicações da classe operária procurava incorporá-las em sua proposta de governo. Em campanha, destacou as transformações e problemas do país, com ênfase na corrupção política, no descaso dos governantes para com o povo, nas deficientes condições de vida e trabalho do operariado, na questão da educação (BARROS; MACHADO, 2006, p. 81-82).

A produção cafeeira permitiu uma crescente acumulação de capitais, que, em parte, era investido na construção de estradas de ferro e em fábricas, associado à entrada de capital estrangeiro, impulsionou mudanças na economia e no aumento populacional concentrado em algumas grandes cidades. O êxodo rural e a imigração exigiam um rápido processo de urbanização e, ao mesmo tempo, aumentavam a classe operária e a exploração do trabalho assalariado. Por meio do assalariamento, eram contratados homens, mulheres e crianças, de diferentes idades e nacionalidades, submetidos a longas jornadas de trabalho, sem hora-extra remunerada ou descanso, sem seguro saúde ou maternidades, entre outros. Por isso, a essa classe dirigiu a maior parte de seus discursos, entendia que os trabalhadores eram os mais importantes do país, já que eles se elevavam em inteligência e modernidade. Alertava as classes conservadoras para a ameaça sofrida pelo capitalismo e a falta de regulamentação do trabalho nas fábricas.

Rui Barbosa, no seu discurso proferido no Teatro Lírico de São Paulo, em 20 de março de 1919, nessa segunda campanha presidencial, deu destaque ao descaso dos políticos para com a população:

\begin{abstract}
Senhores:
Conheceis, porventura, o Jeca Tatu, dos Urupês, de Monteiro Lobato, o admirável escritor paulista? Tivestes, algum dia, a ocasião de ver surgir, debaixo desse pincel de uma arte rara, na sua rudeza, aquele tipo de uma raça, que, "entre as formadoras da nossa nacionalidade", se perpetua, "a vegetar, de cócoras, incapaz de evolução e impenetrável ao progresso"?[...]

Não sei bem, senhores, se, no tracejar deste quadro, teve o autor só em mente debuxar o piraquara do Paraíba e a degenerescência inata da sua raça. Mas a impressão do leitor é que, neste símbolo de preguiça e fatalismo, de sonolência e imprevisão, de esterilidade e tristeza, de subserviência e hebetamento, o gênio do artista, refletindo alguma coisa do meio, nos pincelou, consciente, ou inconscientemente, a síntese da concepção que têm da nossa nacionalidade os homens que a exploram. (BARBOSA, v. XLVI, t. II, 1956, p. 63-65).
\end{abstract}

Ao tratar da "Questão Social e Política no Brasil", Rui Barbosa destacou, assim, o desgoverno que imperava no país e o desrespeito dos legisladores para com ele. Estes se acostumaram a ver seus contemporâneos como "[...] a caboclada lerdaça e tardoada da família do herói dos Urupês, a raça despatriada e lorpa, que vegeta, como os lagartos, ao sol, na madraçaria e lombeira dos campos descultivados" (BARBOSA, v. XLVI, t. II, 1956, p. 66). Cabe, frente a esta afirmação, repetir uma questão que o próprio Rui Barbosa se fez: Seriam os governantes que pensavam o Brasil desta forma? Ou era assim que o Brasil seria constituído? Respondendo à sua indagação, no fervilhar de seu discurso, ele mostrou que o Brasil era muito mais do que um país de politiqueiros, era muito mais do que um país constituído por corruptos, era, sobretudo, constituído por "células ativas da vida nacional", isto é, por trabalhadores. Além da corja corrupta, o país possuía operários. Era para estes trabalhadores que Rui Barbosa dirigiu seu discurso, mostrando que o trabalho santificava as criaturas, gerava coisas boas, justas e úteis. 
Alertava que uma das questões que precisava ser regulamentada era a da moradia. Habitualmente, eram casas sem ar, nem luz: ambiente promíscuo que atestava a miséria em que viviam. Referia-se, ainda, à falta de legislação com relação ao trabalho do menor, à jornada de trabalho, à higiene do ambiente de trabalho, à assistência à gestante, entre outras. Rui Barbosa, ao enumerar alguns problemas dos trabalhadores que precisavam ser solucionados com urgência, afirmava que "[...] a sorte do nosso trabalho, é a sorte, [...] da nossa indústria, como da nossa agricultura, e, portanto, a sorte do país. Feito não há nada. Tudo por fazer." (BARBOSA, v. XLVI, t. II, 1956, p. 94).

Ainda durante sua segunda campanha presidencial, na Bahia, ele discursou sobre a necessidade de se fazer reformas nacionais no sentido de colocar em erupção, o vulcão da democracia e da liberdade. Segundo ele, o Brasil carecia de reforma eleitoral, de reforma de ensino, de saneamento, de legislação trabalhista. Assim, ao reconhecer que alguns indivíduos imaginavam que no Brasil não existia esse vulcão, o movimento operário em erupção, ele asseverava que os fatos estavam a desmentir essa idéia e a sua eclosão deveria ser prevenida. Era preciso que o país se preparasse para não ser pego de surpresa, deveriam permanecer dormindo aqueles que só acordavam com as explosões. Em todos os locais do globo, estava-se reivindicado democracia, essa se propagava, deslocava-se e se universalizava. Nos mais diferentes pontos do mundo, respiravam-se as mesmas influências liberais, as mesmas necessidades liberais. Sobre esta questão discursou às classes conservadoras, no dia 8 de março de 1919 no Salão da Associação Comercial do Rio de Janeiro, apontando a corrupção política como o maior mal do Brasil. Os políticos eram corruptos, enganosos e falsos e, apesar disso, as classes conservadoras nada faziam para mudar a situação. As classes conservadoras tinham importante papel na sociedade por representar a propriedade e o trabalho, constituindo-se pelas forças vivas da sociedade: trabalho, capital, ciência, lavoura, indústria, comércio e instrução. (BARBOSA, v. XLVI, t. I, 1956, p. 13-14). Segundo nosso candidato, esta classe deveria lutar por seus interesses, já que seria prejudicada se mantivesse a situação vigente. Deveria se associar aos trabalhadores, por meio do voto, para destruir o "parasitismo" e o "mal político" existente no Brasil, contudo ela não estava sozinha: "[...] todos esses participam dos elementos conservadores da comunidade." (BARBOSA, v. XLVI, t. I, 1956, p. 11).

Defendia que o Estado poderia intervir em algumas atividades, como no caso da relação capital e trabalho, devido às transformações vivenciadas, com o crescimento do movimento socialista. Criticou, ainda, os governos republicanos que, até aquele momento, nada tinham feito pelos trabalhadores. Estes tinham direitos de cidadão, todos os direitos individuais e civis, tal como os demais brasileiros, tinham direito a todas as garantias constitucionais. Era preciso leis equiitativas para regular as relações peculiares do trabalho com o capital:"[...] o operário tem todos os direitos civis, e, dotado, como os demais brasileiros de todas as garantias constitucionais, não queixa se não de que às relações peculiares do trabalho com o capital não corresponda um sistema de leis mais eqüitativas, a cuja sombra o capital não tenha meios para abusar do trabalho." (BARBOSA, v. XLVI, t. I, 1956, p.79). Esses problemas sem soluções se deviam à corrupção política condenada anteriormente por ele, de modo que "[...] as duas maiores necessidades nossas na ordem física e moral, o ensino e a higiene, ainda não merecem a criação do ministério da Instrução e da Saúde Pública, advogada por mim há quase quarenta anos". (BARBOSA, v. XLVI, t. I, 1956, p. 16). Como esses ministérios não haviam sido criados, nesse discurso, ele descreveu os três problemas principais enfrentados pelos operários que eram a justiça, a instrução e a habilitação para o trabalho. Eram necessárias leis para regulamentar a situação do trabalho operário, bem como era preciso promover a instrução, preparando-os para o trabalho. Considerava que os programas educacionais, propostos no final do império (18821883), poderiam, se tivessem sido implantados, mudar a situação do operário. Argumentou:

Na sorte do operário culminam três problemas capitais: a justiça; a instrução; a nobilitação do trabalho.[...] A minha obra de empenho, nas câmaras imperiais, foi a reforma do ensino público, trabalho que mereceu proclamado na Europa 
como o mais considerável de todos os até ali existentes na história do Parlamento brasileiro. E quem teria ido mais longe do que eu, em serviços às classes trabalhadoras no Brasil, se a política, nos quase quarenta anos de então a hoje, em vez de me pilhar ali à toa as idéias, houvesse dado à instrução popular o desenvolvimento, com que o meu projeto a organizava? (BARBOSA, v. XLVI, t. I, 1956, p. 43-45).

Fez referência aos pareceres ao retomar a idéia de que não poderia propor nada novo, porque as questões já postas ainda não haviam sido executadas. Nessa campanha, pouco tratou da questão educacional, procurou concentrar sua argumentação na melhoria das condições de trabalho e de vida dos operários na medida em que se acelerasse o processo de modernização. Mostrou-se indignado com a exploração do trabalho infantil ao denunciar que as crianças trabalhavam desde os sete anos em condições insalubres, eram maltratadas, executavam trabalhos em excesso para suas forças sem receber nenhum tipo de formação profissional. Embora, afirmou Rui Barbosa em 23 de janeiro de 1891, fora expedido um decreto para regularizar o trabalho das crianças nas fábricas da capital, ele não havia sido regulamento, continuando a exploração infantil: “[...] destarte, pois, durante não menos de trinta anos, um após o outro, se, continua a imolar as milhares de crianças. [...] Terrível hecatombe de inocentes cuja responsabilidade se averba toda ao débito da nossa politicalha, da sua crua indiferença, da sua gélida insensibilidade (BARBOSA, v. XLVI, t. I, 1956, p. 90). Para as regulamentações que se faziam necessárias, era preciso realizar uma revisão constitucional, ponto já apontado durante a Campanha Civilista, ofertando ao legislativo poder para adoção das medidas que levariam à regulamentação do trabalho e a melhoria de vida dos trabalhadores. Para tanto, era importante a conscientização dos trabalhadores do poder decisivo de seu voto. Terminada essa malograda eleição, foi para a Bahia apoiar um candidato de oposição. Em 1921, renunciou à cadeira de senador, porém seu mandato foi renovado. No ano de 1922, Artur Bernardes assumiu o poder, Rui Barbosa, porém, não acompanhou esse governo, retirando-se, em seguida, da vida pública (GONÇALVES, 2000a), ao ficar adoentado, retirou-se para Petrópolis. Faleceu em primeiro de março de 1923.

\section{CONSIDERAÇÕES FINAIS}

Rui Barbosa teve uma vida intensa como demonstrado em alguns aspectos privilegiados nesse artigo. Nossa intenção foi permitir ao leitor conhecer as várias facetas desse educador brasileiro, com destaque para alguns aspectos que envolveram o seu posicionamento no que se refere à questão da educação. Esta foi privilegiada ao lado da compreensão que o autor nutria acerca da sociedade brasileira: esta precisava de reformas para modernizar-se.

Nesse processo, o Estado teria papel primordial, pois tomaria as medidas necessárias para viabilizar a modernização. Dentre as várias medidas, era necessária a difusão da escola pública tanto a primária, quanto a secundária, bem como defendeu nos pareceres e nas campanhas políticas a necessidade da criação das universidades. Era premente que o Estado financiasse e difundisse o ensino oficial, sem ele o país nunca se equipararia aos países civilizados.

Em suas facetas constatou-se que sua ação foi sempre direcionada para as reformas burguesas impostas para a manutenção da sociedade de classes, à medida que o movimento social impunha novos problemas, ele fora incorporando em seus discursos e buscava soluções. Reiteradamente anunciava que a realidade nacional pouco realizava no que se referia à educação, desse modo ela continuava como problema a ser resolvido na pauta diária das discussões no Brasil. Para fundamentar seu discurso referia-se a sua proposta educacional explicitada nos pareceres: defendia a necessidade de organização dos sistemas nacionais de ensino, organizando o ensino desde o jardim de infância até o ensino superior, gratuito, obrigatório e laico. 


\section{REFERÊNCIAS}

A IMPRENSA. Rio de Janeiro, ano 1, n. 1, 1898.

ALENCAR, José de. Dois escritos democráticos de José de Alencar: Sistema representativo, 1868; Reforma eleitoral 1874. (Organizado por Wanderley Guilherme dos Santos). Rio de Janeiro: Editora da UFRJ, 1991.

ASSIS BARBOSA, Francisco de. In: FUNDAÇÃO Casa de Rui Barbosa. Bibliografia da campanha civilista. Rio de Janeiro: Fundação Casa de Rui Barbosa, 1981.

ATHAYDE, Austregésilo de. Prefácio. In: BARBOSA, Rui. A Ditadura de 1893 [Jornal do Brasil]. Obras Completas. Vol. XX, tomo II ao IV. Rio de Janeiro: Ministério da Educação e Saúde, 1949.

BARBOSA, Rui. Discursos na Assembléia Provincial da Bahia. Obras completas. v. V, tomo I. Rio de Janeiro: Fundação Casa de Rui Barbosa, 1983.

. Discursos parlamentares (Câmara dos Deputados). Obras completas. v. VI e VII, tomo I. Rio de Janeiro: Ministério da Educação e Saúde, 1945.

. Reforma do Ensino Secundário e Superior. Obras completas. v. IX, tomo I. Rio de Janeiro: Ministério da Educação e Saúde, 1942.

Discursos parlamentares. Centenário do Marquês de Pombal. O desenho e a arte industrial. Obras completas. v. IX, tomo I. Rio de Janeiro: Ministério da Educação e Saúde, 1948.

. Reforma do ensino primário e várias instituições complementares da instrução pública. Obras completas. v. X, tomo I ao IV. Rio de Janeiro: Ministério da Educação e Saúde, 1947a.

Discursos parlamentares. Emancipação dos escravos. Obras completas. v. XI, tomo I. Rio de Janeiro: Ministério da Educação e Saúde, 1945.

Abolicionismo. Obras completas. v. XII, tomo I. Rio de Janeiro: Fundação Casa de Rui Barbosa, 1988.

. Questão militar. Abolicionismo. Trabalhos Jurídicos. Swift. Obras completas. v. XIV, tomo I. Rio de Janeiro: Ministério da Educação e Saúde, 1955.

.Queda do Império (Diário de Notícias). Obras completas. v. XVI, tomo I ao VIII. Rio de Janeiro: Ministério da Educação e Saúde: 1947b.

A Constituição de 1891. Obras completas. v. XVII, tomo I. Rio de Janeiro: Ministério da Educação e Saúde, 1946.

A ditadura de 1893 [Jornal do Brasil]. Obras completas. v. XX, tomo II ao IV. Rio de Janeiro: Ministério da Educação e Saúde, 1949.

A Imprensa. Obras completas. v. XXVI, tomo I ao III. Rio de Janeiro: Ministério da Educação e Cultura, 1979a. 
A Imprensa. Obras completas. v. XXVI, tomo III ao VII. Rio de Janeiro: Ministério da Educação e Cultura, 1954.

. A Imprensa. Obras completas. v. XXVI, tomo III ao VI. Rio de Janeiro: Ministério da Educação e Cultura, 1979b.

A Imprensa. Obras completas. v. XXVIII, tomo II. Rio de Janeiro: Ministério da Educação e Cultura, 1979c.

Excursão eleitoral. Obras completas. v. XXXVII, tomo I. Rio de Janeiro: Ministério da Educação e Cultura, 1967.

. Campanha presidencial. Obras completas. v. XLVI, tomo I e II. Rio de Janeiro: Ministério da Educação e Cultura, 1956.

BARROS, Aparecida Vânia Petrini de; Machado, Maria Cristina Gomes. A questão social e política no Brasil em 1919: a visão de Rui Barbosa. Acta Sci. Human Soc. Sci., Maringá, v. 28, n. 1, p. 81-91, 2006.

BASTOS, Tavares. A província. São Paulo: Nacional; Brasília: INL, 1975.

BEVILÁQUA, Débora Boaventura Sá. Rui Barbosa em campanha: a educação na plataforma de governo em 1910. Maringá, Universidade Estadual de Maringá, 2003. (Monografia de Curso de Especialização em Educação Pública).

BINZER, Ina von. Os meus romanos, alegrias e tristezas de uma educadora alemã no Brasil. Rio de Janeiro: Paz e Terra, 1994.

CARDIM, Ermano. Rui Barbosa, o jornalista da República. In: LACERDA, Virgínia Cortes de (Org.). Rui Barbosa: escritos e discursos seletos. Rio de Janeiro: Nova Aguilar, 1995.

CHACON, Vamireh. Manifesto do centro e programa do partido liberal. In: NABUCO DE ARAÚJO, José Thomaz. O centro liberal. Brasília: Senado Federal, 1979. p. 1 a 25.

FAUSTO, Boris. História do Brasil. São Paulo: Editora da Universidade de São Paulo, 2003

FUNDAÇÃO Casa de Rui Barbosa. Rui Barbosa: cronologia da vida e obra. Rio de Janeiro: Fundação Casa de Rui Barbosa, 1995.

GONÇALVES, João Felipe. Rui Barbosa: pondo idéias no lugar. Rio de Janeiro: FGV, 2000a.

GONÇALVES, Vera Teresa Valdemarin. O liberalismo demiurgo. Estudo sobre a reforma educacional projetada nos Pareceres de Rui Barbosa. São Paulo: Cultura Acadêmica, 2000b.

HOBSBAWM, E. Era dos extremos. São Paulo: Schwarcz, 1995.

LACOMBE, Américo Jacobina. À sombra de Rui Barbosa. Rio de Janeiro: Fundação Casa de Rui Barbosa, 1984.

LACOMBE, Américo Jacobina; SILVA, Eduardo; BARBOSA, Francisco de Assis. Rui Barbosa e a queima dos arquivos. Rio de Janeiro: Fundação Casa de Rui Barbosa, 1988. 
LEONEL, Zélia. Contribuição à história da escola pública. (Elementos para a crítica da teoria liberal da educação). Campinas, Faculdade de Educação, Universidade Estadual de Campinas, 1994. (Tese de Doutorado)

LOCKE, John. Segundo tratado sobre o governo. São Paulo: Abril Cultural, 1983.

LOURENÇO FILHO. A pedagogia de Rui Barbosa. São Paulo: Melhoramentos, 1956.

LUSTOSA, Isabel. Rui, jornalista. In: LUSTOSA, Isabel et al.. Estudos históricos sobre Rui Barbosa. Rio de Janeiro: Casa de Rui Barbosa, 2000.

MACEDO, Joaquim Manuel. As vítimas algozes. Quadros da escravidão. São Paulo: Scipione; Rio de Janeiro: Fundação Casa de Rui Barbosa, 1991.

MANN, Horace. A educação dos homens livres. São Paulo: IBRASA, 1963.

MACHADO, Maria Cristina Gomes. Rui Barbosa: pensamento e ação: uma análise do projeto modernizador para a sociedade brasileira com base na questão educacional. Campinas: Autores Associados; Rio de Janeiro: Fundação Casa de Rui Barbosa, 2002.

. Fontes e história das instituições escolares: o projeto educacional de Rui Barbosa no Brasil. In: LOMBARDI, José Claudinei; NASCIMENTO, Maria Isabel Moura. Fontes, história e historiografia da educação. Campinas, SP: Autores Associados, 2004. p. 65-85.

. O Decreto de Leôncio de Carvalho e os pareceres de Rui Barbosa em debate - A criação da escola para o povo no Brasil no século XIX. In: STEPHANOU, Maria; BASTOS, Maria Helena Câmara. História e memórias da educação no Brasil. v. II. Petrópolis: Vozes, 2005. p. 91-103.

. Estado e educação "em preto e branco": a atuação de Rui Barbosa no Diário de Notícias (1889). In: SCHELBAUER, Analete Regina; ARAÚJO, José Carlos Souza (Orgs.). História da educação pela imprensa. Campinas: Alínea, 2007. p. 31-52.

. Rui Barbosa. Recife: Fundação Joaquim Nabuco, Editora Massangana, 2010.

MACHADO, Maria Cristina Gomes; ARAÚJO, José Carlos Souza. Metamorfoses do pensamento liberal de Rui Barbosa: sua posição sobre Estado e Educação. Revista Diálogo Educacional. Curitiba, PUCPR, v. 5, n. 14. p. 113 - 124. jan./abr. 2005.

MACHADO, Maria Cristina Gomes; MÉLO, Cristiane Silva. Rui Barbosa: Estado e educação na imprensa em 1889. Revista HISTEBR On-line. Campinas, FAE UNICAMP, v.1, n.25, p. 106 121. mar. 2007.

MANGABEIRA, João. O estadista da república. São Paulo: Livraria Martins, 1960.

MAgAlHÃES, Rejane Mendes Mareira de Almeida. Rui Barbosa na Vila Maria Augusta. Rio de Janeiro: Fundação Casa de Rui Barbosa, 1994. 
PINTO, Virgílio Noya. Balanço das transformações econômicas do século XIX. In: MOTA, Carlos Guilherme. (Org). Brasil em perspectiva. Rio de Janeiro: Bertrand do Brasil, 1995. p. 122-141.

RODRIGUES, Ricardo Vélez. A propaganda republicana. In: Curso de introdução ao pensamento político brasileiro. Brasília: Ed. UnB, 1982.

SMITH, Adam. A riqueza das nações. São Paulo: Abril Cultural, 1998.

VERÍSSIMO, José. A educação nacional. Porto Alegre: Mercado Aberto, 1985. ${ }^{1}$ Este artigo em sua origem compunha o livro "Rui Barbosa" de minha autoria (MACHADO, 2010). Para adequação
ao formato da Coleção Educadores - MEC, publicado pela Fundação Joaquim Nabuco, Editora Massangana,
algumas partes foram cortadas. Estas foram reorganizadas para serem publicadas no formato de artigo. Recomenda-
se a leitura concomitante desse artigo e do supracitado livro para o conhecimento da nossa leitura da obra de Rui
Barbosa.
${ }^{2}$ A Fundação Casa de Rui Barbosa preserva e divulga a obra de Rui Barbosa, bem como se constitui em centro de
pesquisa sobre a sociedade brasileira conforme afirma Magalhães (1994). Ver o site www.fcrb.gov.br.
${ }_{3}^{3}$ Este trabalho foi desenvolvido junto ao Grupo de Pesquisa "História Educação, Intelectuais e Instituições Escolares", cadastrado no Diretório do CNPq, e ao Grupo "História, Sociedade e Educação no Brasil" HISTEDBR.

${ }^{4}$ Sobre o esse conselheiro, escreveu Gonçalves (2000a, p. 27): "Este, além de melhor amigo de João José, era o maior líder do Partido Liberal baiano à época em que Rui se formou. Sua enorme influência acabaria levando Rui à Câmara provincial e logo à imperial. Sem esse tipo de apadrinhamento, numa época em que as eleições eram absolutamente controladas por jogos internos de uma pequena elite, Rui nunca teria se lançado como político em nível nacional." A intimidade com os Dantas se estreitaria com sua amizade com Rodolfo Dantas, filho do conselheiro.

${ }^{5}$ Gonçalves (2000a, p. 35) escreveu sobre seu início de vida parlamentar: "Seu segundo discurso importante foi em defesa de uma atitude do governo imperial: ter dado o poder a um gabinete liberal e convocado novas eleições. Desta feita, foi a duração do discurso, de quatro horas, que mais despertou atenção. Essa característica de seus discursos prontamente se incorporou à sua imagem popular. No dia seguinte, a Revista Ilustrada publicou uma caricatura que o mostrava como um boneco de corda sob a legenda: 'Corda garantida por 24 horas. Privilegiado pelo Governo Imperial'. A partir desse momento, a vida e atuação de Rui tornar-se-iam uma verdadeira festa para os caricaturistas. Ainda nesse ano surgiriam caricaturas chamando atenção para seu aspecto físico que mais se popularizariam: o avantajado volume de sua cabeça e sua pequena estatura $(1,58 \mathrm{~m})$ ".

${ }^{6}$ Rui Barbosa manteria estreita relação com a tendência liberal (RODRIGUES, 1982), ficou conhecido por divulgar o modo de vida americano, sendo inegável também o fascínio demonstrado pelas instituições inglesas.

${ }^{7}$ Buarque de Holanda destaca, ao referir-se à questão eleitoral, que o próprio Imperador nunca deixava de lembrar da necessidade de manter a exigência de renda mínima, como também o saber ler e escrever. Essa idéia já havia se alastrado no país, o progresso do saber era tido como fonte milagrosa de virtudes. Para ele, a educação, sobretudo a instrução primária, era uma necessidade fundamental do povo. Seu raciocínio poderia ser desenvolvido da seguinte forma: "[...] sem educação popular não se pode esperar boas eleições; sem boas eleições não se pode esperar regime representativo; sem regime representativo não haverá democracia; sem democracia é excusado querer que a Coroa não intervenha no processo político; por conseguinte, torna-se inevitável o poder pessoal sem educação popular" (BUARQUE DE HOLANDA, 1972 apud MACHADO, 2002, p. 62).

${ }^{8}$ Sobre a importância da imprnsa para Rui Barbosa sugere-se a leitura de Machado e Mélo (2007).

${ }^{9}$ Rui Barbosa procurou estimular o desenvolvimento da indústria brasileira, para tanto, acreditava ser necessária a tomada de medidas que aumentassem a emissão de papel moeda de maneira a facilitar o crédito no mercado financeiro, bem como concedia a bancos privados o direito de emitir moedas. Buscou estabelecer leis que facilitassem a criação de sociedades anônimas e criou um novo regime alfandegário para dificultar a entrada de produtos estrangeiros. Sua política levou ao encilhamento, assim analisado por Pinto (1995, p. 143): "Este período, denominado Encilhamento, caracteriza-se pela desordem econômica e pela especulação desenfreada e nociva. Esta especulação se faz sentir sobre o câmbio, comércio, indústria, propriedade, etc. E tem repercussões nas agitações políticas do início da República".

${ }^{10}$ Uma de suas ações como ministro, que causou muita polêmica, foi o ato em que ele mandou queimar papéis, livros de matrículas e documentos sobre a escravidão, guardados no Ministério da Fazenda. Lacombe, Silva e Barbosa (1988, p. 37) organizaram o livro Rui Barbosa e a Queima dos Arquivos com o intuito de esclarecer o acontecido. Para esses autores, a ação de Rui Barbosa teve como objetivo extinguir comprovantes fiscais que 
poderiam ser utilizados pelos ex-proprietários de escravos como documento para exigir do Estado indenização pelos escravos libertos em 1888. Esta lei não reconheceu o título de proprietário dos senhores de escravos e os libertou sem nenhum pagamento, gerando um movimento para que se cobrasse essa indenização. Em fins de 1890, foi solicitado o pagamento pelos escravos libertos ao que Rui Barbosa respondeu: "Mais justo seria, e melhor se consultaria o sentimento nacional se se pudesse descobrir meio de indenizar o ex-escravo não onerando o tesouro. Indeferido. 11 de novembro de 1890". A ordem para queimar os artigos foi escrito um mês após esse despacho, o que permitiria estabelecer uma relação entre essas ações. Essa medida, naquele momento, foi recebida pela imprensa com entusiasmo patriótico e, no Congresso Constituinte, muitos políticos influentes parabenizaram o Governo Provisório por esta medida, como Serzedelo Correia, Epitácio Pessoa e Joaquim Murtinho. Isto revela que essa ação não pode, isoladamente, ser atribuída a Rui Barbosa.

11 Este jornal foi fundado em 9 de abril de 1891, por Rodolfo de Souza Dantas e Joaquim Nabuco. Rui Barbosa legou numerosos artigos em quatro meses de atuação nesse jornal, de 5 de maio 1893 a 6 de setembro do mesmo ano. Saiu do Governo Provisório com a intenção de repousar, com alguma resistência voltou a escrever, em suas páginas, explicava a política econômica que adotou quando foi ministro da Fazenda em função da crítica recebida por meio do anonimato da imprensa, sem avaliar conscientemente o valor educativo do jornal. Ele não ia à redação do jornal, enviava os seus artigos com comentários sobre os principais acontecimentos do dia, em sua maioria, eram artigos de caráter político nos quais discutia as ações do governo de Floriano Peixoto e buscava defender ou explicar a Constituição brasileira. Nessa fase, Rui Barbosa se expunha abertamente contra o arbítrio do então presidente o que podia gerar retaliações e foi, por diversas vezes, posto como inimigo da República. Acompanhou, por este jornal, a Revolução Federalista do Sul e a defesa do Wanderkolk, entre outras questões. Com o levante da esquadra comandada por Custódio José de Melo, Rui Barbosa teve de exilar-se embora não tivesse participado desse movimento, mas pela oposição ao governo estabelecido. (BARBOSA, v. XX, t. II, 1949).

12 Nesse jornal, Rui Barbosa veiculava as mais variadas notícias, seu formato era $65 \mathrm{~cm}$ de altura e 49 de largura, seguindo os padrões da época. Trazia telegramas com notícias curtas sobre problemas nacionais e internacionais, possuía coluna específica para divulgar notícias sobre os estados e para as de origem estrangeira, bem como notícias sobre o Congresso e notícias políticas. Informava sobre a Prefeitura Municipal, o Ministério da Fazenda, o Exército e Armada, cada um desses itens possuía título com destaque. O número de páginas do jornal variava de quatro a oito, dependendo do dia, aos domingos e feriados, os jornais eram mais extensos. A maior parte delas estava destinada aos anúncios nos quais alguns apresentavam gravuras, estas dividiam espaços com a divulgação de notícias policiais, de informações sobre o comércio, sobre esportes, loterias, teatro, entre outras. O jornal, também, divulgava notas sociais e acontecimentos de interesse da cidade. Como exemplo destaca-se uma nota, divulgada no dia 16 de outubro (A IMPRENSA, 1898, n. 1, p. 2), intitulada Gymnasio Nacional, no qual se noticiava que havia sido realizada uma homenagem a José Veríssimo pelo trabalho de diretor durante sete anos nesse estabelecimento, e nele revelou sua dedicação à educação. Tratava dos mais variados assuntos, como o nacionalismo, o voto estrangeiro, o monopólio e greves de trabalhadores. Ver Barbosa (v. XXVI, t. I ao III, 1979a; v. XXVI, t. III ao VII, 1954; v. XXVII, t. III ao IV, 1979b; v. XXVIII, t. II, 1979c).

${ }^{13}$ Como exemplo, podemos citar Mangabeira (1960, p. 100), este escreve que, em Haia: "Ruy foi a figura principal. Disso não pode duvidar quem leu ou quer ler o volume em oitavo grande dos seus Atos e Discursos na Segunda Conferência da Paz [...] Primeiro pelo talento, pela cultura e pela flama de apóstolo que arde nas suas palavras e o alenta na sua intransigência triunfante. E triunfante contra todos os obstáculos e todas as desvantagens".

${ }^{14}$ Sobre a disposição de Rui Barbosa ser presidente da República, Gonçalves (2000a, p. 108-109) faz a seguinte afirmação: "E era de domínio público o antigo desejo de Rui de chegar à presidência da República. [...] Isso não significava o abandono de seus ideais políticos de liberação e de democratização da República. Pelo contrário, Rui percebia que esses ideais não teriam a menor chance de se efetivar sem uma ação estratégica inteligente que lhe desse algum tipo de poder. Era em nome desses ideais que ele se aliava politicamente - a aliança tornou-se uma questão de sobrevivência política não apenas sua, mas de suas propostas. Os fins de Rui continuavam os mesmos; o que mudava eram os meios". Assim, a cada canditatura eram necessárias inúmeras alianças o que provocava em nosso autor inúmeras desilusões.

${ }^{15}$ Os discursos proferidos nas campanhas para Presidente da República e suas plataformas políticas constituem-se em importantes fontes pouco estudada no âmbito da História da Educação.

Recebido em 03/03/2011

Aprovado em 30/03/2011

Revista HISTEDBR On-line, Campinas, n.41, p. 32-60, mar2011 - ISSN: 1676-2584 